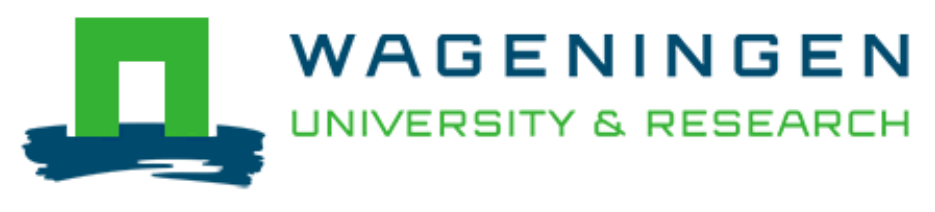

\title{
An Economic Rationale for the West African Scramble? The Commercial Transition and the Commodity Price Boom of 1835-1885
}

Frankema, E. H. P., Williamson, J. G., \& Woltjer, P. J.

This is a "Post-Print" accepted manuscript, which has been published in "J ournal of Economic History"

This version is distributed under a non-commercial no derivatives Creative Commons (c) $(\mathcal{Q} \Theta \Theta(\mathrm{CC}-\mathrm{BY}-\mathrm{NC}-\mathrm{ND})$ user license, which permits use, distribution, and reproduction in any medium, provided the original work is properly cited and not used for commercial purposes. Further, the restriction applies that if you remix, transform, or build upon the material, you may not distribute the modified material.

Please cite this publication as follows:

Frankema, E. H. P., Williamson, J. G., \& Woltjer, P. J. (2018). An Economic Rationale for the West African Scramble? The Commercial Transition and the Commodity Price Boom of 1835-1885. J ournal of Economic History, 78(1), 231-267. DOI:

$10.1017 /$ S0022050718000128

You can download the published version at:

https://doi.org/10.1017/S0022050718000128 


\title{
An Economic Rationale for the West African Scramble? The Commercial Transition and the Commodity Price Boom of 1835-1885
}

\author{
EWOUT FRANKEMA, JEFFREY WILLIAMSON, \\ AND PIETER WOLTJER
}

\begin{abstract}
We use a new trade dataset showing that nineteenth century subSaharan Africa experienced a terms of trade boom comparable to other parts of the "global periphery." A sharp rise in export prices in the five decades before the scramble (1835-1885) was followed by an equally impressive decline during the colonial era. This study revises the view that the scramble for West Africa occurred when its major export markets were in decline and argues that the larger weight of West Africa in French imperial trade strengthened the rationale for French instead of British initiative in the conquest of the interior.
\end{abstract}

The Journal of Economic History, Vol. 78, No. 1 (March 2018). (C) The Economic History Association. All rights reserved. doi:

Ewout Frankema is Professor, Wageningen University, Hollandseweg 1, 6706 KN Wageningen, The Netherlands. E-mail: ewout.frankema@wur.nl. Jeffrey Williamson is Professor, Harvard University and University of Wisconsin, 350 South Hamilton Street, Madison, WI 53703. E-mail: jwilliam@fas.harvard.edu. Pieter Woltjer is Postdoctoral Researcher, Wageningen University, Hollandseweg 1, 6706 KN Wageningen, The Netherlands. E-mail: p.j.woltjer@gmail.com. Dr. Woltjer is the corresponding author.

We are indebted to Paul Rhode and Ann Carlos, whose help has guided us to substantially improve the article. Furthermore, we are grateful to Gareth Austin, Luis Bértola, James Fenske, Leigh Gardner, Jens Andersson, three anonymous referees, and the participants of the African Economic History Workshop, the RIDGE Workshop on Comparative studies of the Southern Hemisphere in global economic history and development, the Workshop on Colonialism, Growth and Development in the Southern Hemisphere, 1800-2000, and seminar participants at Oxford University, Warwick University, and Wageningen University for their comments on earlier drafts. We are responsible for all errors. We acknowledge financial support from the European Research Council (ERC Grant Agreement no. 313114) and the Netherlands Organisation for Scientific Research (NWO VIDI Grant no. 016.124.307). We thank Loes Oudenhuijzen, Jasmijn Appels, Rolinde de Haan, and Rens van Baren for excellent research assistance. 
The scramble for Africa stands out as a remarkable feat of European imperialism and its motives and timing have been long debated (Pakenham 1992, p. xxi-xxii). In less than two decades (1884-1898), the lion's share of the vast African continent was partitioned among a handful of European powers. To be sure, the string of coastal settlements that had been established in support of the trade in slaves, gold, ivory, and other tropical products, testified to European encroachment for centuries. The Cape settlement had functioned as a provisioning station for the trade with Asia already since 1652. The conquest of Algiers in 1830 already demonstrated a French ambition to create an imperial "backyard" across the Mediterranean. French and British interference in Egyptian affairs in the early 1880s also had a clear objective: they guaranteed European control over the Suez and secured the interests of European investors in Egyptian bonds. ${ }^{1}$ But the lures of power and profit were far less obvious in the vast sub-Saharan African interior, and the costs of permanent colonization were high. ${ }^{2}$

This article scrutinizes the economic motivations for the scramble of West Africa by zooming in on trade developments in subSaharan Africa in the long nineteenth century, and by assessing these trade developments in a global comparative perspective. Our overarching argument is that trade developments from the mid-1830s to mid-1880s did more to strengthen the economic rationale for the scramble than most of the historical literature has hitherto assumed. This argument has two aspects.

The first aspect relates to the idea that African markets were too insignificant to lure major European powers into a large-scale military conquest anyway. This view has become mainstream through the influential work of Ronald Robinson and John Gallagher (1961), who argued that internal African political changes pulled Britain into the scramble to safeguard its geo-political interests, and which were focused on securing access to Asia, not to protect or enhance trade with Africa. This view has been extensively debated among historians in the wider context of finding a plausible hierarchy of explanations for the scramble (Hargreaves 1960; Pakenham 1992; Chamberlain

\footnotetext{
${ }^{1}$ For a general discussion of Britain and the African partition, see Cain and Hopkins (1993, pp. 303-39); for the occupation of Egypt, see Hopkins (1986); for the occupation of Algeria, see Sessions (2011).

${ }^{2}$ Sub-Saharan Africa refers to the entire continental area south of the Sahara Desert. Throughout this article, we refer to territories with their original names (albeit assigned by Europeans) and provide modern country names in parentheses whenever we deem necessary for non-specialist readers to keep track. In addition, we provide a map in Appendix 1 which shows the colonial borders around 1914 for the whole of Africa.
} 
2009) as well as British colonial expansion in general (Platt 1973; Fieldhouse 1973; Hyam 1976; Cain and Hopkins 1980). ${ }^{3}$

We show that British-African trade comprised a tiny share of total British imperial trade, but that the share of West African exports in total French imperial trade was significant and growing. AfroEuropean trade patterns in the nineteenth century were thus consistent with the French initiative in 1879 to survey the possibilities of connecting the Middle Niger delta to their commercial entrepôts on the Senegalese coast. We will not claim that nineteenth century trade developments explain the scramble for West Africa for national political prestige, intra-European tensions, religious zeal and, indeed, internal African politics all played their part. What we argue is that during the nineteenth century the costs of colonial conquest were declining as a result of innovations in transportation, communication, military, and medical technology, while the revenues of legitimate commerce were rising, thus narrowing the gap between costs and benefits of colonization. The nineteenth century commodity export boom was crucial in shaping an economic context in which the partition of Africa became politically defensible. When analyzed in a global comparative perspective, the West African terms of trade boom was exceptionally steep in the five decades before the Berlin Conference (1884-1885).

The second aspect relates to the timing of the scramble. Instead of occurring in a period of declining export markets for African commodities, as Anthony Hopkins (1973, pp. 124-35) as well as David Eltis and Lawrence Jennings (1988, p. 942) have argued, we show that the relative prices of most West African tropical export commodities continued to rise up to the mid-1880s. Increasing relative prices between 1853 and 1885 accounted for one-third of the export value growth to Britain, and even 55 percent of the export value growth to France. Hopkins' argument that the scramble was provoked by internal African conflicts emerging from a notable drop in the terms of trade after the 1860s, has been mainly informed by an analysis of British-African trade in palm oil (p. 133). ${ }^{4}$ We show that for the key commodities in French-African trade, in other words gum and groundnuts, there was no such decline. French plans to construct a railway into the West African interior were already circulating since the 1850s, and the eventual initiative to effectuate these plans was aided by a growing weight of Senegambia in French imperial trade.

This prolonged export boom must be considered in the wider context of what is now commonly referred to as the "commercial transition" from slave exports to commodity exports (Law 1995). Figure 1 illustrates this transition for West Africa. It shows that annual

\footnotetext{
${ }^{3}$ See Ratcliffe (1981) for a discussion of the methodological problems inherent to historical research on the link between economics and the partition of Africa. ${ }^{4}$ See also Dike (1956).
} 
nominal revenues from slave exports into the Atlantic economyexcluding slaves traded within Africa-rose to a maximum in the era 1760-1808, when the share of commodity trade was below 10 percent of total West African exports. However, commodity exports overtook slave exports in the 1830s, and around 1850 these reached a temporary peak comparable to the one in slave exports half a century earlier. By the 1880s the nominal value of commodity exports was clearly higher, and would never revert to eighteenth century revenue levels again.

There is a clear temporal sequence in the "commercial transitions" across sub-Saharan Africa: it first occurred in West Africa, then in West-Central Africa, and finally in East Africa. The gradual abolition of the African slave trades and the transition to commodity exports halted the continuous drain on already-scarce labor and spurred land-extensive tropical agriculture engaging smallholder family farms, communal farms, and large estates. ${ }^{5}$ Although these major shifts in African trade are all connected in a globalizing world economy, a comprehensive and comparative survey of Africa's external commodity trade over the long nineteenth century does not exist yet. Inconsistent and incomplete primary sources have long hampered the construction of century-long time series on commodity trade.

Figure 1 is constructed from a new dataset of African commodity trade which we introduce in this article. This dataset contains export and import prices, trade volumes, export composition, and net barter terms of trade (NBTT hereafter) from the British slave trade abolition (1807-1808) to the eve of WWII (1939). Our dataset is a major improvement over existing datasets in terms of its temporal and spatial coverage, the number of commodities included, and the disaggregated level of annual unit export price observations at the African coast. Our dataset focusses on the sea-bound trade of Africa, and primarily, though not exclusively, its trade with Europe. The biggest limitation of our dataset is that it excludes intra-African overland trade.

The onset of colonial rule deepened and diversified African specialization in tropical commodity exports. Colonial states took control over sea-bound trade by imposing tariffs and forced cultivation schemes of export crops, while levying trade and direct taxes to finance the project of colonial state formation (Frankema 2011; Gardner 2012). During the Great Depression and especially WWII, colonial governments started to regulate African commodity trade through price controls and export monopolies maintained by marketing boards (Bauer 1956; Meredith 1986). Colonial rule also

\footnotetext{
${ }^{5}$ The literature on the slave trades, the abolition, and the commercial transition is vast. See for general surveys of these developments, Austen (1979). For the Atlantic slave trade and the abolition, see Klein (2010); for the Indian Ocean slave trade, see Clarence-Smith (1989); for the commercial transition in West Africa, see Law $(1993,1995)$.
} 
facilitated the construction of railways and related inflows of foreign capital, and led to profound changes in the governance of land and labor markets. Colonial regimes set out to abolish slavery, but replaced it by alternative forms of labor coercion on a significant scale (van Waijenburg 2015). The effects of opening up the African interior were hard to miss: between 1897 and 1913 the total value of subSaharan African commodity exports rose by more than 150 percent, from about $£ 71$ million to about $£ 184$ million (Forbes-Munro 1976, p. 86). European colonization and African responses to new commercial opportunities thus accelerated the trend of nineteenthcentury commodity export growth and, at the same time, reduced Africa's opportunities to escape the trap of primary commodity specialization during the prolonged terms of trade decline from 1885 to 1939.

\section{THE COMMERCIAL TRANSITION}

The nineteenth century expansion of world trade was driven by three fundamental forces: a transport revolution, a liberal trade policy move in industrial Europe, and an acceleration in world GDP growth associated with the industrial revolution. ${ }^{6}$ New transportation and communication technologies such as railroads, steamships, the telegraph, and the invention of the refrigerator, helped integrate world commodity markets, lowered price gaps between exporters and importers, and fostered trade between the industrial "core" and the commodity-exporting "periphery." Falling trade costs from all sources accounted for more than half of the trade boom between 1870 and 1914, and probably accounted for even more than that before 1870 when transport costs declined even more rapidly (Jacks, O’Rouke, and Williamson 2011, p. 529). ${ }^{7}$

The move by the European industrial core towards a more liberal commercial policy, a commitment to the gold standard, and probably imperialism itself all made additional contributions to the nineteenth-century world trade boom (Estevadeordal, Frantz, and Taylor 2003; Meissner 2005; Ferguson 2004; Mitchener and Weidenmier 2008). Rapid manufacturing productivity growth in the industrial core lowered supply costs and output prices, adding to the demand for inexpensive factory-made manufactures, and by doing so generated a soaring derived demand for raw materials, and industrial intermediates, like fuels, fibers, dyes, rubber, oils, fine woods, and metals. In the industrializing core, manufacturing growth outpaced GDP growth, and was reinforced by a high-income elasticity of demand for consumption goods such as meat, dairy products, dried

\footnotetext{
${ }^{6}$ This section draws in part on Williamson (2011, Chapter 1).

${ }^{7}$ See for seminal studies on the relation between transport cost declines and nineteenth century growth of international trade: North (1958) and Harley (1988).
} 
fruit, sugar, tobacco, tea, cocoa, and coffee. All of these forces produced a powerful, century-long terms of trade boom in the "peripheral" commodity exporters, as the prices of their imported manufactures fell and those of their commodity exports rose. ${ }^{8}$ Yet, even though trade made it possible for the periphery to share some of the fruits of the industrial revolution taking place in the core, globalization also fostered de-industrialization in the periphery so that income per capita growth rates diverged. ${ }^{9}$

The transport and communication revolutions not only lowered trade costs, they also reduced the costs of military conquest and colonial control. New innovations in weapon technology (e.g., gun boat, maxim gun) enhanced European military superiority and major advances in medical knowledge (quinine) reduced the high mortality and morbidity rates of overseas expeditions, and made treatment of tropical diseases much more effective. Of course, this drop in the costs of conquest made the scramble for Africa feasible, but not necessarily desirable (Curtin 1989).

Most of sub-Saharan Africa became part of the nineteenthcentury world trade boom by shifting from slave exports to the export of ivory, groundnuts, copra, palm oil, palm kernels, beeswax, gum, dyewoods, sugar, rubber, cotton, minerals, and precious stones. The British considered the promotion of "legitimate trade" as a cornerstone of their "civilization mission" and the related suppression of internal and external African slave trades. ${ }^{10}$ Hopkins (1973) has argued that the abolition of the external slave trade provoked a "crisis of adaptation" because some slave trading areas had more suitable environmental conditions to shift towards tropical commodity exports than others. ${ }^{11}$ Moreover, the production of agricultural cash-crops for export markets involved a different business model than the production of slaves. Whereas slave raiding demanded a military hierarchy to secure violence monopolies and distribute slave trade revenues, the production of agricultural commodities could be conducted as efficiently by large numbers of small farmers, as by large-scale producers employing slave labor, the former favoring a model of atomistic competition over state monopoly. According to Hopkins (1973, p. 124) the implications of the commercial transition

\footnotetext{
${ }^{8}$ Only China and Cuba were exceptions, Williamson (2011, p. 236).

${ }^{9}$ See for case-studies on Mexico: Dobado, G'omez-Galvarriato, and Williamson (2008); India: Clingingsmith and Williamson (2008); Turkey: Pamuk and Williamson (2011); and Egypt: Panza and Williamson (2015).

10 The idea was that slavery within Africa could only be abolished by developing viable economic alternatives. The famous Niger expedition of 1841, which ended in a complete failure, was motivated by precisely these two objectives: to conclude treaties with local African chiefs to end slavery, and to explore the possibilities for plantation agriculture along the Niger river. See Temperley (1991).

11 See for further reflections on Hopkins' "crisis of adaptation" thesis the various contributions to the volume edited by Law (1995), including his introduction to this volume (1995, pp. 1-31).
} 
for the re-organization of markets marked the start of the "modern economic history" of West Africa, that is, the economic structures that emerged during the commercial transition were to exist up until the close of the colonial era (1973, p. 294).

Later studies have emphasized that the commercial transition was more evolutionary than revolutionary, since adaptation in most cases did not produce a crisis. ${ }^{12}$ David Northrup (1976) has argued that palm oil exports in the Bight of Biafra rose together with slave exports in the early nineteenth century before replacing the latter. ${ }^{13}$ The joint expansion was facilitated by the market networks (port facilities, merchant relations, credit instruments) that had evolved under the slave trade. ${ }^{14}$ Martin Lynn (1995, p. 59) has extended this argument noting that market entry in the palm oil trade remained controlled by existing rulers and merchant groups. Paul Lovejoy (2005, pp. 162-76) has argued that the abolition induced a reallocation of slaves for Atlantic markets towards local and transSaharan markets and showed how plantation agriculture (e.g., cotton, indigo, grains) used large amounts of slave labor in the Sokoto Caliphate (part of present-day Northern Nigeria). Gareth Austin (1995, pp. 95-100; 2005, pp. 46-47), discussing the Asante monopolies on kola nut and gold production, has argued that the emergence of new African and Atlantic markets for respectively kola nuts exported to Hausaland (Northern Nigeria) and gold smoothed the transition in the Gold Coast area (Ghana). Susan Martin (2006, pp. 189-90) and Robin Law (1995, p. 196) have pointed out that part of the evolutionary changes also occurred in the domain of household and gender relations.

The commercial transition in East Africa occurred later. Despite British treaties to curb the slave trade with the Sultan of Zanzibar in the 1820s and 1830s, slave exports into the wider Indian Ocean area expanded up to the last quarter of the nineteenth century,

\footnotetext{
12 See several contributions to the edited volume by Law (1995). See for a direct critique Hopkins (1968), Ajayi and Austen (1972, pp. 303-306), and Hopkins (1972) reply. The case of Dahomey may still be seen as an example of a crisis of adaptation, with slave exports collapsing in the 1830 s to 1850 s, while palm oil exports were slow to pick up. See Manning (1982, p. 332).

${ }^{13}$ This also ties into the question as to the extent to which the growth of the Atlantic slave trade in the long eighteenth century had "crowded out" commodity exports, or instead had stimulated production of tropical crops for Atlantic markets in the wake of expanding commercial infrastructure and related (financial) institutional developments. This remains a contested topic in terms of both theoretical viewpoints (in other words Marxist versus Smithian interpretations) as well as interpretations of the empirical evidence. See for Marxist views Rodney (1972); Inikori (2002). See for a Smithian perspective, Thornton (1998).

${ }^{14}$ Gemery, Hogendorn, and Johnson (1990, pp. 163-64) argue on the basis of British custom ledgers that British non-slave imports from Africa increased fivefold during the eighteenth century. Eltis (2013, pp. 31-33), on the other hand, has estimated that the annual value of commodity exports was rather volatile, but overall hardly grew between 1700 and 1800, while its share of total exports collapsed from circa 41 percent to 7 percent. See also Doorn, Lindblad, and Touwen (1990).
} 
when British military and diplomatic pressure eventually enforced a formal prohibition of the slave trade by sea in 1873 (Sheriff 1988, p. 133). As a result, the hinterland of Mozambique was entrenched in the Atlantic slave trade up to the 1850s, but it also supplied slaves to Madagascar, the Comoros, the Mascarenes, and further destinations in the Indian Ocean (Campbell 2004, 2008). Compared to the estimates of the Atlantic slave trade, the figures for the export of slaves into the Persian Gulf and South Asia remain mere guesstimates, but there appears to be a consensus that this trade reached its peak between 1850 and 1873, and that about half of the guesstimated 1.6 million slaves being taken out of East and Central Africa during the nineteenth century were retained on the East African coast (Austen 1988, p. 41; Lovejoy 2011, p. 156).

The Eastbound slave trades were complemented by the export of ivory from the interior, as well as cloves produced with slave labor at the coast. Oil seeds (e.g., sesame) and copal were also exported, albeit in very small quantities (Clarence-Smith 1989; Sheriff 1987; Cooper 1974). Yet, the size of the commodity trade remained much lower in East than in West Africa throughout the nineteenth century. In the 1890s, imports from British East Africa were valued at a little over three million pounds, whereas imports from British West Africa totaled nearly 25 million pounds. ${ }^{15}$ These figures reflect the fact that the "cash-crop revolution" in East Africa, which included tobacco, cotton, sesame, flax, coffee, and tea, did not really start until after 1900, when railways removed the transportation bottlenecks for perishable bulk commodities (Tosh 1980; Jedwab and Moradi 2016). Given the much stronger orientation of European trade on the African Atlantic, it is not surprising that European colonization of the deeper African interior started in West Africa, which was wealthier and more densely populated (Frankema and van Waijenburg 2012).

\section{A NEW DATABASE OF AFRICAN TRADE}

In the 1970s and 1980s, a series of pioneering studies documented the transition from slave to commodity exports (ForbesMunro 1976; Hanson 1980; Liesegang, Pasch, and Jones 1986; Eltis and Jennings 1988; Law 1993). However, these studies focused on parts of the nineteenth century or on trade in a few commodities, with none based on a comprehensive dataset of African trade for the entire nineteenth century. More recent work on African terms of trade has either focused on a single commodity, or considered post-1870 trade developments, including terms-of-trade analyses but for different analytical purposes (Deaton 1999; Allen 2011; Prados de la Escosura

${ }^{15}$ Data obtained from the Statistical Abstract for the Several Colonial and Other Possession of the United Kingdom (1890-1899). 
2012).$^{16}$ Within the limitations of the available historical sources, our dataset has a larger spatial and temporal coverage and includes more product detail. We gathered our data from primary trade accounts and merged these with several existing series to produce annual timeseries of export volumes, export values, commodity export prices, import prices, and NBTT series. Our data cover more than 50 products including foodstuffs, cash-crops, forest products, metal ores, and minerals. The series were built up from spatially disaggregated sources and were weighted up to aggregate trade and price series. This allows us to analyze aggregate African trade developments in a global perspective and it also allows us to explore trends at the regional or product level. ${ }^{17}$

For 1808-1829 most of our observations are drawn from British trade with West and South Africa listed in the handwritten British Customs Records. We drew French trade with West Africa from the French import statistics. For the African islands, our pre1830 series focus on sugar, which covered more than 80 percent of the islands' export value, and for the East African coast our data up to 1890 are based on ivory exports derived from the work of Abdul Sheriff (1986). For the post-1830 era our dataset covers exports and imports of nineteen areas in sub-Saharan Africa for which we obtained price information at the African coast. Post-1830 British data is drawn from the Colonial Blue Books, the Statistical Abstract for the Several Colonial and Other Possession of the United Kingdom and the Statistical Abstract for the United Kingdom. Post-1830 French data comes primarily from the Tableau General du Commerce de la France avec ses Colonies et les Puissances etrangeres. We identify these regions with the names given to the "colonies" that emerged during the late nineteenth century.

In West Africa, we distinguish the Gold Coast (present-day Ghana), Gambia, Nigeria, Sierra Leone, the French West African Coast (covering Mauritania, Guinea, Ivory Coast, Togo, and Benin), and Senegal. In East Africa, we distinguish Northern Rhodesia (Zambia), Nyasaland (Malawi), Kenya and the Uganda Protectorate, Somaliland (Somalia), Tanganyika (Tanzania), and Zanzibar. The African islands include Madagascar, Mauritius, and Reunion. For South Africa, we have trade data for the Cape Colony, Natal (merged into the Union of South Africa in 1910), and Southern Rhodesia (Zimbabwe). For North Africa, we included data from Egypt drawn ${ }^{16}$ Deaton (1999) focuses on the twentieth century; Allen (2011) offers prices of palm-oil
(1817-1997) and cocoa (1854-1994) relative to cotton cloth, even though he seems to be
unaware that cocoa played no role in African exports until after the scramble; Prados de la
Escosura (2012) uses post-1870 export price series to estimate GDP series from Hanson
(1980) and Bairoch and Etemad (1985). But in this 2012 study he does not analyse African
trade.
17 The full dataset and source description is available at: www.aehnetwork.org/data-
research/african-commodity-trade-database/ 
from the work of Laura Panza and Jeffrey Williamson (2015). We also gathered data for Portuguese Africa and the Congo Free State (later Belgian Congo), but we focus here on the areas that came under British and French control, which constituted more than 90 percent of total continental commodity trade throughout the nineteenth century.

We constructed export price indices using annual prices quoted at African ports for 1830-1939 and extrapolated these indices backwards to 1808 using American wholesale prices, converted into British pounds using official exchange rates (Bezanson, Gray, and Hussey 1937; Officer 2015). ${ }^{18}$ Where several commodity prices were available from different areas, we weighted each by its volume share in total African exports. French prices were converted to British pounds using quoted exchange rates (Mitchell 1988, pp. 700-703). Where African price data were missing for the 1830-1939 period, we interpolated the commodity price indices based on the British wholesale prices trends (Sauerbeck 1886-1951).

Figure 2 presents the growth in exports of the four most important commodities in nineteenth century sub-Saharan Africa from 1850 to 1910, excluding South Africa. Palm oil was the key commodity in the first half of the nineteenth century. Palm oil was used as a machine lubricant (including the railways), as an ingredient in soap production, and as an edible oil in food processing industries. After 1850 gum and especially groundnuts became more important and were the two principal export items from the Senegambia area (present-day Senegal and the Gambia). Groundnuts were particularly valued as a source of protein-rich vegetable oil, finding its way mainly into European food industries. Gum was used for all sorts of industrial purposes, but was especially valued for its adhesive qualities and demanded by textile, food, and chemical industries. After 1880, a number of other export commodities gained ground such as rubber, cocoa, and cotton.

Sub-Saharan Africa was a small player in world trade, even though its share of world trade increased in the century between 1850

\footnotetext{
${ }^{18}$ We based our index on export prices quoted at African ports instead of prices quoted on European markets for three reasons. Firstly, not all the key African export commodities are listed in the British or French wholesale price index series. Secondly, some of the products that are listed in the African sources may be of a different quality or have certain characteristics that distinguish them from the commodities listed on the European markets; e.g., wood. Thirdly, prices observed at the African coast may differ from those quoted in London or Paris. Comparing price levels for four key African commodities (palm oil, rubber, hides, and raw cotton) reveals a strong correlation between coastal and London prices for all commodities (between 0.73 and 0.94 ), except for palm oil (0.36). Comparing annual growth rates reveals a strong correlation for the coastal and London price series for hides and cotton (0.86 and 0.72 , resp.), but not for rubber and palm oil ( 0.37 and 0.39 ). A cointegration test finds that the London and African time series for palm oil are cointegrated, as is the case for hides and cotton. The null hypothesis of no cointegration for rubber, however, cannot be rejected at the standard 5 percent significance level. The reasons why price trends diverge for some years or periods are difficult to determine and beyond the scope of this article. However, for the derivation of African NBTT it is crucial to base prices for African export commodities on unit values observed at the African coast.
} 
and 1950. This does not imply, however, that all African export commodities were insignificant. In the decades before the scramble, West Africa was the world's leading supplier of palm-oil, palm kernels, gum, and groundnuts. The Gold Coast became market leader in cocoa beans in 1911 and maintained this status to the late 1970s (Austin 2005, p. 2). East African ivory dominated world markets in the nineteenth century and Central African exports of wild rubber were significant before Southeast Asian plantations took over in the 1910s (Clarence-Smith 2013, p. 193). Especially palm-oil, gum, and groundnuts from West Africa and rubber from the Congo basin were highly valued industrial inputs. European merchants who had invested in these trades were eager to control and expand the trade. ${ }^{19}$ From the 1840 s to the 1880s, the composition of British and French imports also shifted. British merchant companies concentrated increasingly on the palm-oil trade with the Gold Coast and Southern Nigeria, while French companies invested increasingly in the gum and groundnut trades in the Senegambia area from about 1850 onwards.

Figure 3 presents the trend in total French and British imports from West Africa. While both increased, their timing and magnitude differed. In the 1830s and 1840s the average annual value of British imports from West Africa was distinctively larger. However, around 1850 the total value of French imports from West Africa overtook the total value of British imports. Between 1850 and 1880 the growth was more or less comparable, but these figures hide the important fact that around 1880 the per capita exports from Senegal were much higher than from Nigeria, even exceeding a ratio of 10:1, since the former area was far less densely populated than the latter. ${ }^{20}$ Finally, Figure 3 shows that during the scramble exports from French West Africa fell much more than did exports from British West Africa. This drop was mainly caused by declining volumes, rather than by declining prices. It shows that the military campaigns of the French had a much more disruptive effect on trade, which is consistent with the generally accepted view that the French had to fight longer and harder to "pacify” Africans (Boahen and M’Baye Gueye 1985).

In Tables $1 \mathrm{~A}$ and $1 \mathrm{~B}$ we present the share of African colonies in total exports to Britain and France along with trade from other colonies from 1860-1939. While continuing to be dominated by India, Ceylon, and Southeast Asia, the African share of exports to Britain grew from seven to 25 percent over the period. Table 1A shows that African commodity trade to Britain was dominated by

${ }^{19}$ See for a detailed discussion of African and European interests in the Nigerian palm-oil trade Dike (1956). See for French trade Kanya-Forstner (1988). See for a general overview Newbury (1988).

${ }^{20}$ For these calculations, we used the official exchange rates of the gold standard regime, in which one British Pound equaled 26 French Francs. We took population estimates for Nigeria and Senegal from Frankema and Jerven (2014). 
South Africa and Mauritius up to the 1880s, but that the West and East African shares increased from 1890 and 1910, respectively. In Table 1B we show that African exports to France dominated imperial trade in a similar way as Indian exports dominated British imperial trade. Africa was central to French colonial imports. North Africa, and Algeria in particular, made up the bulk of this trade ranging between 33 and 64 percent. Still, the share of West African exports to France was substantial as well, hovering around 10 to 15 percent in the decades before the scramble. Following the decline of the French Caribbean trade during the late nineteenth century, the share of West African exports to France was only matched by exports from Indochina. We excluded exports from the British dominions such as Australia and Canada, but if these were added, the difference in the relative weight of African exports in British and French imperial trade would appear even larger. Indeed, French trade on the Senegambia had a very different standing in the context of empire than British trade on the Gold Coast or the Niger delta.

\section{THE COMMODITY PRICE BOOM OF 1835-1885}

We now bring the "commercial transition" in sharper focus by exploring the timing as well as the comparative magnitude of subSaharan Africa's nineteenth century commodity price boom. We calculate the NBTT as the ratio of the weighted average of all major commodity export prices to commodity import prices, and use this information to calculate annual average growth rates of the purchasing power of African exports.

To obtain an aggregate export price index for each area/colony, the country's commodity prices were weighted using its export mix. These export weights were changed at approximately 20year intervals to capture long-run shifts in export composition. ${ }^{21}$ The

\footnotetext{
${ }^{21}$ Modern index-number literature emphasizes that weights need to be updated at regular intervals to reflect changing expenditure patterns and incorporate new products in the weighting baskets (Diewert 2014). Setting fixed, time-invariant weights will introduce a sizable bias at any given point in time. Commonly, long indices are constructed using a procedure called chaining, where aggregate price indices are calculated for shorter, partly overlapping sub-periods which are subsequently joined together by rescaling them to make the values equal in the overlapping years. However, if there are considerable fluctuations in the prices and quantities in the intervening periods, chaining may both increase the index number spread and even distort the measure of the overall change between the first and last periods. A solution is to reduce the frequency of chaining and thus lengthen the sub-periods. This can smooth out temporary shocks to prices or quantities and compensate for measurement error in the weights. These issues are particularly relevant for our NBTT series which spans a long time-period, sees the introduction of various new export and import commodities, exhibits a fair amount of volatility in both the prices and quantities for those commodities, and inevitably suffers from some measurement error. We adopt a chaining procedure, setting the chain length at 20 years, and averaging the weights over each subperiod. Our methodology not only matches the standard practice in the historical trade literature (Blattman, Hwang, and Williamson 2007; Williamson 2011), it also closely mirrors the methodology currently applied by the World Bank and the IMF (2009). A robustness
} 
commodity specific quantity information for 1830-1939 is based on the same sources as the export price data described earlier. Countryspecific export price indices were aggregated to obtain regional series, matching the five regions described in the previous section. The aggregate indices were constructed using area/colony nominal export shares. These weights were also changed at 20-year intervals to capture the shift in each area's contribution to the value of total African exports. Regional specific terms of trade were derived by dividing the export price indices by a common import price index (Mitchell 1988, pp. 526-28), to capture change in the prices for the primary British manufactures shipped abroad. The use of a common African import price index implies that we do not take differences in the import mix of individual African colonies into account. We conducted a sensitivity analyses based on the quantity and prices of imported goods from the United Kingdom into Africa (observed at the African coast) to check for possible biases caused by compositional effects. In addition, we compared a price index of British commodities to an index of French commodities being traded with the rest of the world. The results are shown in the Online Appendix and indicate that the British index by Brian Mitchell (1988) appears to be a good proxy for the price development of imported goods into Africa.

Figure 4 shows the evolution of the NBTT index for British and French West Africa combined. The NBTT rose modestly up to the mid-1830s, but increased rapidly from then to the mid-1880s. The secular commodity price and terms of trade boom is consistent with other tropical commodity exporting countries in Latin America and Southeast Asia: from 1835 to 1885 their terms of trade doubled, or increased at an annual rate of 1.9 percent, which was larger than per capita income growth in the poor periphery, and even greater than per capita income growth in the United Kingdom (1.2 percent per annum, 1820-1870), as estimated by Angus Maddison (1995, p. 23). However, as also shown in Figure 4, the fall from the peak in the mid1880s to 1939 eroded all the gains which producers and traders in West Africa had experienced from the early 1800s onwards. This terms-of-trade decline that has received far more attention than the huge boom that preceded it (Prebisch 1950; Singer 1950; Lewis 1978).

These new NBTT estimates for English colonial trade differ distinctively from the gross barter terms of trade (GBTT) series

check of our NBTT index for West Africa (WA) between 1808 and 1884 reveals that alternative choices of chain lengths do not fundamentally alter our findings. Setting the chain length as high as 50 years or as low as two years yields estimates of average annual NBTT growth ranging from 1.51 to 1.87 percent. Our preferred estimate of 1.65, based on 20-year intervals, sits comfortable in the middle of this range. Setting the chain length to one, thus updating weights every year, results in an average annual growth rate of NBTT for WA between 1808 and 1884 of 2.38 percent. This substantially higher growth rate is likely the result of chain drift. 
offered by Eltis and Jennings (1988, p. 943), as shown in Table $2 .^{22}$ Although both indices confirm that the African terms of trade improved over the course of the early nineteenth century, the rate of growth in the two series show different patterns. We observe a takeoff in the 1830s peaking in the mid-1880s (as shown in Figure 4). The Eltis and Jennings series suggested that the African terms of trade more than doubled, translating into an annual rate of growth of 2.1 percent between the second half of the 1810s and the early 1850s. Our estimates indicate the terms of trade to have grown by a little under 1.3 percent per annum between 1816 and 1853, nearly 40 percent less than their estimate.

Although Eltis and Jennings (1988, p. 942) were unable to link their early nineteenth century estimates to the post-1853 period, they contended that the terms of trade rise "probably continued until the last third of the nineteenth century, when a sharp reversal occurred." Here they echo Hopkins' (1973, p. 133) claim, based on his analysis of nominal palm-oil prices, that "the barter terms of trade moved decisively against primary producers" in the third quarter of the nineteenth century. Our estimates show that the aggregate terms of trade peaked later, in the middle of the fourth quarter of the nineteenth century, because the terms of trade of other West African export commodities such as gum and groundnuts continued to rise up to the mid-1880s.

There are three reasons why the NBTT series are to be preferred over GBTT series to capture long-term changes in relative prices (Obstfeld and Rogoff 1996). First, the GBTT series measure relative changes in the volume of exports over the volume of imports. This is a good measure of purchasing power only if the current and capital accounts are balanced, as a trade deficit funded by international loans or unrequited transfers would cause the GBTT to be more favorable than the NBTT. However, these assumptions were clearly violated in nineteenth-century Africa when volatile trade gaps were cleared by sizable flows of gold and capital. ${ }^{23}$ The NBTT measure does not assume that the trade balance is zero. Second, for aggregated trends the GBTT requires a set of prices for a given base year to convert the nominal value of all goods and services traded into real values. Eltis and Jennings relied on the official values reported in the British customs ledgers, which were based on late seventeenthcentury prices. These official values are not representative for the trade flows observed in the nineteenth century, which contained several new export products that had seen sizable increases in their traded volume accompanied by falling prices.

\footnotetext{
${ }^{22}$ The GBTT is the ratio between the volume of a country's imports and exports, whereas the NBTT is the ratio between the prices of a country's imports and exports.

${ }^{23}$ The Statistical Abstract for the Several Colonial and Other Possession of the United Kingdom provides a detailed summary of capital flows.
} 
Third, aggregating together quantities of all goods imported and exported does not allow one to detect the impact of a change in volume of a single commodity on the terms of trade. NBTT estimates allow us to focus strictly on commodities, to single out the effect of individual goods on the overall terms-of-trade trend, and to reweight the index at 20-year intervals to more adequately reflect the changing export mix over time. Finally, since Eltis and Jennings did not extend their GBTT index into the post-1850 era, they missed a vital part of the commercial transition in West Africa and, indeed, the full extent of the African terms of trade boom of 1835-1885.

The use of the NBTT measure allows us to disentangle the effects of changes in import prices and in export prices as well as the growth in the volume of exports on the purchasing power of African exports. Table 3 illustrates this for West Africa. In the period up to 1885, during the height of the terms-of-trade boom, export price growth enhanced the purchasing power of exports. Between 1853 and 1885, export volumes rose at an annual rate of 2.23 and 3.14 percent for the French and British possessions, respectively, while the purchasing power of exports (in other words the real value of imports received in exchange for African exports) rose at one-and-a-half or double those rates: 4.96 and 4.65 percent respectively. Contrary to the views of Hopkins and Eltis and Jennings, the real revenues from West-African exports did not contract during the third quarter of the nineteenth century, but rose at an impressive rate. The change in the price for commodity exports (relative to the price of imports) accounted for more than half of the increase in the purchasing power of exports for French West Africa and nearly a third for British West Africa.

After 1885, the terms of trade went into sharp decline, reflecting the fact that export prices rose more slowly than the prices for imported goods. The terms-of-trade decline notwithstanding, the purchasing power of exports still rose between 1885 and 1929. This was driven exclusively by a pronounced increase in the export volume for both British and French West Africa. Later, we discuss why the export boom continued during the colonial era, despite the sharp decline in the African terms of trade.

\section{AFRICA'S COMMODITY PRICE BOOM IN GLOBAL PERSPECTIVE}

What did West Africa's commodity price boom look like in a global comparative perspective? First, we compare the West African NBBT trends with four other African sub-regions, which are all characterized by rather different export packages: East Africa, the African islands, the Cape Colony (later South Africa), and Egypt. Then, we compare the West African NBTT trend with the European 
Periphery (Italy, Portugal, Russia, Spain), the Middle East (Egypt, Ottoman Turkey, Levant), Latin America (Argentina, Brazil, Chile, Cuba, Mexico, Venezuela), South Asia (Ceylon, India), and Southeast Asia (Indonesia, Malaya, the Philippines, Siam). ${ }^{24}$

Figure 5 shows that the NBTT in other parts of Africa also rose impressively during the nineteenth century, but there are some major differences. Firstly, relative prices of South African commodities such as wool, wine, and hides (diamonds and gold are excluded) did not increase as much as the relative prices of tropical commodities. The boom in East Africa was driven exclusively by ivory prices. In Egypt, the terms of trade were driven by cotton prices which peaked in the 1860s when world supplies dwindled because of the American civil war. Finally, while the rise of the NBTT up to the 1860s was slower in the African islands - where sugar dominatedits peak in the early 1880s was similar to West Africa.

The comparison of West Africa and Africa more generally with other commodity exporters is described in Figure 6. We show the relationships for South Asia, the European periphery, the Middle East, Latin America, and Southeast Asia. South Asia-dominated by India-had a shorter and a weaker nineteenth century terms-of-trade boom than West Africa with the South Asian terms of trade peaking in 1861, a full quarter of a century before the West African peak. Annual average growth of South Asia's NBTT from its trough to boom was just half of what we observe for sub-Saharan Africa (see Table 4). Over the full nineteenth century up to 1885-1890 South Asia recorded no NBTT growth at all, whereas we find an annual average growth of 1.73 for sub-Saharan Africa. Indeed, all the growth in India's terms of trade took place up to the 1820s; after that decade, India exhibited great volatility, but no secular growth in its terms of trade. ${ }^{25}$ The European periphery and the Middle East both had a steeper boom-to-peak than West Africa, but, like South Asia, they were shorter, peaking in 1855 and 1857. The terms of trade for Latin America and Southeast Asia were more like West Africa, which is explained by the larger similarities in the export packages of these three regions.

In Table 4 we convert this visual accounting into annual growth rates. From the late eighteenth century to 1860, the commodity-exporting "periphery" experienced one of the biggest terms of trade booms in world history. The unweighted annual average growth rate of the five regions mentioned earlier-excluding Africa and East Asia—was 1.43 percent per annum. The figure for West Africa was even higher, 1.65 percent per annum. West Africa

\footnotetext{
${ }^{24}$ This section draws on Williamson (2011, Chapter 3).

25 This is an especially ironic finding given that the literature on nineteenth century deindustrialization in British India has been the most copious and contentious by far. See Roy (2002); Clingingsmith and Williamson (2008).
} 
also enjoyed its boom a couple of decades longer than the average poor commodity exporter. Summing up, Hopkins and Eltis and Jennings were surely correct about the rising terms of trade in West Africa, but our new NBTT estimates reveal that the boom was stronger and more prolonged than they have envisaged.

\section{AN ECONOMIC RATIONALE FOR THE WEST AFRICAN SCRAMBLE?}

This new evidence documenting the evolution of nineteenth century Afro-European trade allows us to re-assess the economic rationale for the West African scramble. The relevant historical counterfactual has two elements: would the case for building a railway into the West African interior have been politically defensible if the West African share in French imperial trade would have been as small as it was in British imperial trade? And second, would their ambitions to invade have gathered sufficient political support without the commodity price boom that started around the mid-1830s and continued up to the mid-1880s, a price boom that contributed more than half of the growth in French imports from West Africa? While these counterfactuals are impossible to test in a formal way, we will argue here that the economic rationale for the scramble did not only appear much stronger in the 1880s than in the 1830s, but also that West Africa had a different place in French than in British visions of empire.

During the mid-nineteenth century, the British government took the view that free trade should be promoted without interference in indigenous affairs. Especially with regard to Africa, the Treasury did everything to block increasing expenses on colonial settlements (Hargreaves 1963). In an earlier study, John Gallagher and Ronald Robinson (1953, p. 4) observed that formal policies and historical practices diverged, noting that British warships in Canton (Guangzhou) and the establishment of formal control over major parts of India (the Raj) did not demonstrate a "reluctance" to the expansion of empire, and were motivated by securing British mercantile and capitalist interests. With respect to Africa, they stated that "the West Africa Committee of 1865 made a strong and much quoted case for giving up all but one of the West African settlements, but even as they sat these settlements were being extended." ${ }^{26}$ Gallagher and Robinson argued that the British only opted for the expansion of "formal empire" when their options of informal control (via voluntary or enforced free trade treaties) were undermined by unreliable local trading partners or by European contenders. In later work they went a

\footnotetext{
${ }^{26}$ Dike (1956, p. 181) also noted how the plea of the West Africa Committee for retreat, was inconsistent with increasing British encroachment in the Niger delta in the 1860s.
} 
step further, arguing that the economic rationale for the African scramble was to be found in Asia (Robinson and Gallagher 1961).

Hopkins noted, however, that the British and French did set out to secure those places where they had built up the strongest commercial relations: the French in the Senegambia area, the British around the Volta and Niger basins. He reasoned that European demand for industrial inputs had driven up the price of West African export commodities, but that the price of palm-oil, and many agricultural commodities, had started to fall after the 1860 s as a result of the "great depression" of 1873-1895, so that the timing of the price boom did not align with the timing of the scramble. He contended that falling African commodity prices provoked intra-African conflicts over shrinking export revenues, induced extra tolls and tariffs in compensation, and that the undermining of free trade by Africans motivated European intervention (Hopkins 1972, p. 586).

The Hopkins thesis has been criticized by Ade Ajayi and Ralph Austen (1972, pp. 304-306) who pointed out that the Yoruba wars in Nigeria that Hopkins had referred to were not primarily motivated by considerations of declining external trade revenues, since it accounted for only a small portion of the economic surpluses that were generated in the domestic economy. Moreover, Ajayi and Austen contended that the palm-oil trade in Southern Nigeria was not the main prize of the scramble. Even though the British secured territorial control over Lagos in 1861, they argued that Europeans were primarily concerned with capturing the external and internal trade flows of the major Savannah empires in the middle Niger delta.

Whereas this was certainly true for the French (see later), the British concentrated their efforts on the annexation of Lagos. Hopkins (1980) elaborated his earlier argument by noting that the impetus given to the palm-oil trade by regular steamship connections also required changes in property right regimes, especially with respect to marketable ownership rights over land. The increasing reliance on mercantile credit in societies with non-convertible currencies (in other words cowries) stimulated demand for securities by the European trading community. Such changes in property rights regimes required the presence of a reliable government capable of creating institutions for land transfers and protecting land rights. Although the call of the merchant community for the annexation of Lagos cannot explain the West African scramble as such, the relationship between land rights and territorial control became of imminent importance in later plans for the construction of railways.

The chronology is important. According to Colin Newbury and Alexander Kanya-Forstner (1969, p. 255), French intentions to extend their territorial control over the Western Sudan were already a serious political consideration in the 1850s, and were inspired by the successful conquest of Algeria in the 1830s. The original idea, put 
forward by Senegal's governor Louis Faidherbe, was to create a transSaharan union connecting the Middle Niger delta and the major inland cities such as Bamako, Gao, and Timbuktu, into a triangular network with Algeria to the North, and the Senegambia to the West. Given the growing importance of both areas in French imperial trade, a railway connection with the Savannah empires was perceived as a logical extension of the French African Empire. In the mid-1860s these plans were put on hold, as France was distracted by overseas wars in Mexico and Indochina (Newbury and Kanya-Forstner 1969, p. 256). However, the humiliating defeat in the Franco-Prussian war in 18701871, as well as the continuing expansion of the British overseas empire, kept fueling a political desire to reinvigorate national grandeur (Cain and Hopkins 1993, pp. 329-31).

Meanwhile, Bordeaux merchants trading in Senegambia, enthralled railway engineers and colonial governors kept lobbying for imperial expansion in West Africa. While the costs of invading West Africa appeared insurmountable in the 1850s and 1860s, the French government did approve new funds for strengthening colonial control over the Senegambia area. The reconstruction of the run-down fort at Podor and the construction of a new fort at Médine in the 1850s, were motivated by the need to crush Moorish control over the expanding gum trade (Newbury and Kanya-Forstner 1969, pp. 254, 257). The rapid growth of the groundnut trade in the 1860s commanded the erection of new forts at Boffa, Boké, and Benty (Hargreaves 1963, pp. 129-36). At the same time, colonial investments at the Slave and Ivory coasts (present-day Benin and Côte d'Ivoire), and in particular the French stronghold in Porto-Novo, were scaled back. The prospects of expanding trade with the Senegambia, and contracting trade further South, thus played a key role in the re-allocation of France's imperial budgets.

The fascinating reconstruction of the political chronology by Newbury and Kanya-Forstner (1969, p. 257) reveals that the definitive decision by the French government to invade the West African interior was prepared in 1876-1879, that is before the British occupation of Egypt in 1882. The economic context in which this decision was made was one of depressed trade in Europe, but growing trade with West Africa (see Figure 2). Although there was a price collapse for gum and groundnuts in 1877, with severe fiscal repercussions, this depression was short lived. Figure 7 shows that whereas the relative price of palm oil fell, that for gum and groundnuts continued to rise up to the mid-1880s. These trade developments fueled ex-ante optimism on the economic prospects of penetrating the Senegalese hinterland, even though the envisaged wealth of the Savanah empires, and especially its gold deposits, were exaggerated to mythical proportions (Newbury and Kanya-Forstner 1969, p. 261; Brunschwig 1960, pp. 23-28). 


\section{TRADE AFTER THE SCRAMBLE}

While a more in-depth analysis of trade during and after the scramble warrants a separate study, we conclude by making three general observations. First, although African commodity exports increased throughout the nineteenth century, the price boom was the defining feature of the 1835-1885 period, with export volumes rising as a supply response. What followed was different. The export boom continued, but it coincided with a prolonged fall in commodity prices. That is, commodity exports now grew for reasons other than a supply response to favorable world prices. As shown in Table 3, the postscramble acceleration of export growth was entirely caused by volume growth. This growth in export quantities was facilitated by railroads. European territorial control paved the way for railway investments unlocking the export potential of the African interior. Most of these railways were constructed and completed in the four decades following 1890. Although this export boom involved some diversification into a wider range of tropical commodities and minerals, the overall composition of African exports remained overwhelmingly based on primary commodities. It should also be noted that while sea-bound exports from sub-Saharan Africa to Europe increased exponentially after the scramble, the imposition of colonial borders often disrupted existing intra-African trade relations. ${ }^{27}$

This deepening of specialization in primary commodities during an era of almost continuously worsening terms of trade raises another question. Why did Africa not escape this commodity export trap after world markets soured? We will not try to offer a comprehensive answer to this question here, except to note that an explanation must come from two sources: first, the African endowment of abundant land with scarce capital, labor and skills, an endowment that heavily favored land-extensive agriculture, and mining; and second, colonial policies designed to support specialization in primary commodities (Austin, Frankema, and Jerven 2017). Any attempt to sort out these two forces will have to deal with the evidence in Figure 8, showing that export growth was slower before the 1880s, when prices boomed, and faster after the 1890s, when prices slumped, not only to the detriment of African producers, but also to European investors and plantation-owners. It is also worth noting that the price slump was larger in French Africa than in British Africa, partly because of the declining value of the French Franc after abandoning the gold standard.

Furthermore, the move towards trade liberalization that occurred in Europe during the mid-nineteenth century was

${ }^{27}$ See for the case of French Guinée (Goerg 1980). 
implemented in colonial Africa right at the time that it was starting to reverse in Europe. Colonial governments implemented modest tariff policies, mainly motivated by the need to raise government revenues, not by the desire to protect local producers. Colonial governments promoted the free flow of goods into and out of their territories, and relied on large-scale programs of forced labor to build the necessary infrastructure (Frankema and van Waijenburg 2014). Colonial governments imposed ad valorem import duties around 5 to 10 percent and left exports largely untaxed.

Liberal trade policies came under pressure in the 1930s, when soaring budget deficits forced colonial governments to rethink their models of colonial economic development. Marketing boards were established to strengthen the control of colonial governments on the main export sectors via price controls and monopsonies. The marketing boards were initially intended to stabilize volatile commodity prices and African farm incomes, but the revenues derived from the increasing margins between marketing board purchase prices and world market prices were kept in metropolitan funds and were not channeled back directly into the development of local agriculture (Meredith 1986; Havinden and Meredith 1995). In the settler colonies, where government interventions in markets for labor and land had been more pervasive and biased against African smallholders, colonial policy reforms removed some of the restrictions in the hope to revive commodity exports (Frankema, Green, and Hillbon 2016).

Finally, thanks to the commodity export boom Africa's share of world trade kept rising to about 5 percent in 1950. This share was maintained during the late colonial era up to the early 1970s. The rise itself is not surprising. Africa was the last major world region to be unlocked by railways. Moreover, if the external slave trade had crowded out the development of commodity exports, the slave trades must also have retarded the integration of Africa into world commodity markets. Yet, globalization-induced specialization in primary products also meant greater price volatility, and this compounded the divergence in growth rates during the twentieth century. African export prices collapsed again during the 1970s and only started recovering around 1995-2000. How long Africa's commodity boom will last this time is difficult to say, but one thing seems clear: the recent rise in African terms of trade is far more modest than the 1835-1885 boom.

\section{Appendix 1: Maps}




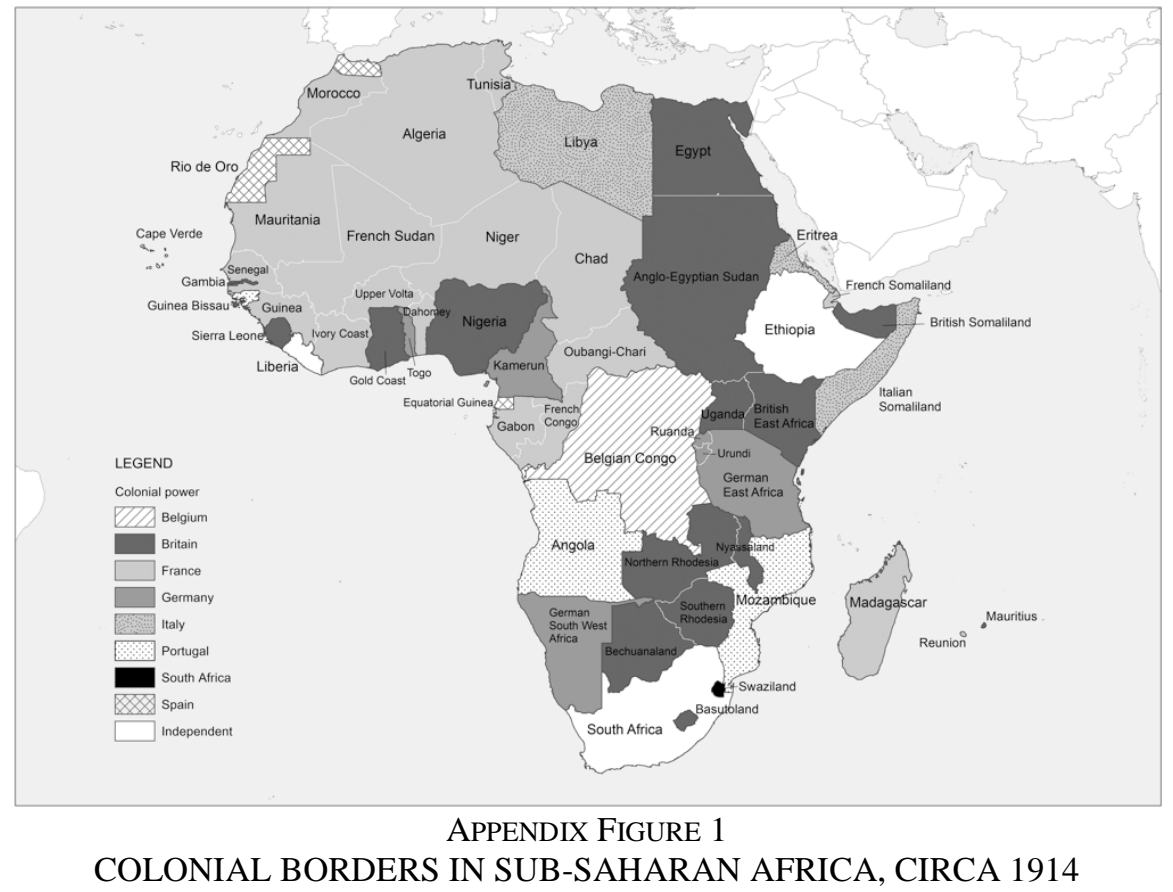

Source: author's own.

\section{REFERENCES}

Ajayi, J. F. Ade, and Ralph A. Austen. "Hopkins on Economic Imperialism in West Africa.” Economic History Review 25, no. 2 (1972): 303-306.

Allen, Robert C. Global Economic History: A Very Short Introduction. Oxford: Oxford University Press, 2011.

Austen, Ralph A. “The Trans-Saharan Slave Trade: A Tentative Census.” In The Uncommon Market: Essays in the Economic History of the Atlantic Slave Trade, edited by Henry A. Gemery and Jan S. Hogendorn, 23-75. New York: Academic Press, 1979.

. "The Nineteenth Century Islamic Slave Trade from East Africa (Swahili and Red Sea Coasts): A Tentative Census.” Slavery and Abolition 9, no. 3 (1988): 21-44.

Austin, Gareth. "Between Abolition and Jihad: The Asante Response to the Ending of the Atlantic Slave Trade, 1807-1896." In From Slave Trade to "Legitimate” Commerce. The Commercial Transition in Nineteenth-Century West Africa, edited by Robin Law, Chapter 4, 93-118. Cambridge: Cambridge University Press, 1995.

- Labour, Land, and Capital in Ghana: From Slavery to Free Labour in Asante, 1807-1956. Vol. 18. Rochester Studies in African History and the Diaspora. Woodbridge: Boydell \& Brewer, 2005.

Austin, Gareth, Ewout Frankema, and Morten Jerven. "Patterns of Manufacturing Growth in Sub-Saharan Africa: From Colonization to the Present." In The Spread of Modern Manufacturing to the Periphery, 1870 to the Present, edited by Kevin H. O’Rourke and Jeffrey G. Williamson, Chapter 14, 345-374. Oxford: Oxford University Press, 2017.

Bairoch, Paul, and Bouda Etemad. Structure Par Produits Des Exportations Du Tiers-Monde, 1830-1937. Geneva: Droz, 1985. 
Bauer, Peter Thomas. “Marketing Monopoly in British Africa.” Kyklos 9, no. 2 (1956): 164-80.

Bezanson, Anne, Robert D. Gray, and Miriam Hussey. Wholesale Prices in Philadelphia 1784-1861. Philadelphia: University of Pennsylvania Press, 1937.

Blattman, Chris, Jason Hwang, and Jeffrey G. Williamson. "The Impact of the Terms of Trade on Economic Development in the Periphery, 1870-1939: Volatility and Secular Change.” Journal of Development Economics 82, no. 1 (2007): 156-79.

Boahen, A. Adu, and M'Baye Gueye. “African Initiatives and Resistance in West Africa, 1880-1914.” In General History of Africa VII. Africa under Colonial Domination 1880-1935, edited by A. Adu Boahen, Chapter 6, 114-48. Oakland: University of California Press, 1985.

Brunschwig, Henri. Mythes et R'ealit'es de l'Imp'erialisme Colonial Francais. Paris: A. Colin, 1960.

Cain, Peter J., and Anthony G. Hopkins. "The Political Economy of British Expansion Overseas, 1750-1914.” Economic History Review 33, no. 4 (1980): 463-90.

- British Imperialism: Innovation and Expansion 1688-1914. New York: Longman, 1993.

Campbell, Gwyn. Structure of Slavery in Indian Ocean Africa and Asia. New York: Routledge, 2004.

- An Economic History of Imperial Madagascar, 1750-1895. Cambridge: Cambridge University Press, 2008.

Chamberlain, Muriel Evelyn. The Scramble for Africa. New York: Routledge, 2009.

Clarence-Smith, William G. The Economics of the Indian Ocean Slave Trade in the Nineteenth Century. London: Frank Cass, 1989.

—. "Rubber Cultivation in Indonesia and the Congo from the 1910s to the 1950s. Divergent Paths.” In Colonial Exploitation and Economic Development. The Belgian Congo and the Netherlands Indies Compared, edited by Ewout Frankema and Frans Buelens, Chapter 9, 193-210. London: Routledge, 2013.

Clingingsmith, David, and Jeffrey G. Williamson. "Deindustrialization in Eighteenth and Nineteenth Century India: Mughal Decline, Climate Shocks, and British Industrial Ascent.” Explorations in Economic History 45, no. 3 (2008): 209-34.

Cooper, Frederick. "Plantation Slavery on the East Coast of Africa in the Nineteenth Century.” Ph.D. diss., Yale University, 1974.

Curtin, Philip D. Death by Migration. Europe's Encounter with the Tropical World in the Nineteenth Century. Cambridge, UK: Cambridge University Press, 1989.

Dalrymple-Smith, Angus, and Pieter Woltjer. Commodities, Prices and Risk: The Changing Market for Non-Slave Products in Pre-abolition West Africa. AEHN Working Paper No. 31. Sussex: African Economic History Network, 2016.

Deaton, Angus. “Commodity Prices and Growth in Africa.” Journal of Economic Perspectives 13, no. 3 (1999): 23-40.

Diewert, W. Erwin. Price Level Measurement. Amsterdam: Elsevier Science Publishing Company, 2014.

Dike, Kenneth O. Trade and Politics in the Niger Delta 1830-1885. Westport, CT: Greenwood Press, 1956.

Dobado, Rafael, Aurora G'omez-Galvarriato, and Jeffrey G. Williamson. "Mexican Exceptionalism: Globalization and De-Industrialization 1750-1877.” Journal of Economic History 68, no. 3 (2008): 1-53.

Doorn, Peter K., Thomas J. Lindblad, and Jeroen Touwen. “The Marion Johnson Data on African Trade.” In Anglo-African Trade in the Eighteenth Century: English Statistics on African Trade 1699-1808, edited by Marion Johnson, 
Thomas J. Lindblad, and Robert Ross, 13-36. Leiden: Centre for the History of European Expansion, 1990.

Eltis, David. "The Slave Trade and Commercial Agriculture in an African context." In Commercial Agriculture, the Slave Trade and Slavery in Atlantic Africa, edited by Robin Law, Suzanne Schwarz, and Silke Strickrodt, 28-53. Woodbridge, Suffolk: James Curry, 2013.

Eltis, David, and Lawrence C. Jennings. "Trade Between Western Africa and the Atlantic World in the Pre-Colonial Era.” American Historical Review 93, no. 4 (1988): 936-59.

Eltis, David, and David Richardson. Extending the Frontiers: Essays on the New Transatlantic Slave Trade Database. New Haven: Yale University Press, 2008.

Estevadeordal, Antoni, Brian Frantz, and Alan M. Taylor. "The Rise and Fall of World Trade, 1870-1939.” Quarterly Journal of Economics 118, no. 2 (2003): 359-407.

Ferguson, Niall. Empire: How Britain Made the Modern World. New York: Penguin, 2004.

Fieldhouse, David K. Economics and Empire, 1830-1914. London: Weidenfeld/ Nicolson, 1973.

Forbes-Munro, John. Africa and the International Economy, 1800-1960: An Introduction to the Modern Economic History of Africa South of the Sahara. Worthing: Littlehampton Book Services, 1976.

Frankema, Ewout. "Colonial Taxation and Government Spending in British Africa, 1880-1940: Maximizing Revenue or Minimizing Effort?” Explorations in Economic History 48, no. 1 (2011): 136-49.

Frankema, Ewout, Erik Green, and Ellen Hillbom. "Endogenous Processes of Colonial Settlement. The Success and Failure of European Settler Farming in Sub-Saharan Africa.” Revista de Historia Econ'omica 34, no. 2 (2016): 1-29.

Frankema, Ewout, and Morten Jerven. "Writing History Backwards or Sideways: Towards a Consensus on African Population, 1850-2010.” Economic History Review 67, no. 4 (2014): 907-31.

Frankema, Ewout, and Marlous van Waijenburg. "Structural Impediments to African Growth? New Evidence from British African Real Wages, 18801965.” Journal of Economic History 72, no. 4 (2012): 895-926.

- "Metropolitan Blueprints of Colonial Taxation? Lessons from Fiscal Capacity Building in British and French Africa, c. 1880-1940.” Journal of African History 55, no. 3 (2014): 371-400.

Gallagher, John, and Ronald Robinson. “The Imperialism of Free Trade.” Economic History Review 6, no. 1 (1953): 1-15.

Gardner, Leigh. Taxing Colonial Africa: The Political Economy of British Imperialism. Oxford: Oxford University Press, 2012.

Gemery, Henry A., Jan Hogendorn, and Marion Johnson. "Evidence on English/African Terms of Trade in the Eighteenth Century." Explorations in Economic History 27, no. 2 (1990): 157-77.

Goerg, Odile. “La Destruction D’un Reseau D’’echange Precolonial: L’exemple De La Guin'ee.” Journal of African History 21, no. 4 (1980): 467-84.

Hanson, John R. Trade in Transition: Exports from the Third World, 1840-1900. New York: Academic Press, 1980.

Hargreaves, John D. "Towards a History of the Partition of Africa." Journal of African History 1, no. 1 (1960): 97-109.

- Prelude to the Partition of West Africa. London: MacMillan, 1963.

Harley, C. Knick. “Ocean Freight Rates and Productivity, 1740-1913: The Primacy of Mechanical Invention Reaffirmed.” Journal of Economic History 48, no. 4 (1988): 851-76.

Havinden, Michael, and David Meredith. Colonialism and Development. Britain and its Tropical Colonies, 1850-1960. London: Routledge, 1995. 
Hopkins, Anthony G. "Economic Imperialism in West Africa: Lagos, 1880-92." Economic History Review 21, no. 3 (1968): 580-606.

- "Economic Imperialism in West Africa: A Rejoinder." Economic History Review 25, no. 2 (1972): 307-12.

- An Economic History of West Africa. London: Longman, 1973.

_. "Property Rights and Empire Building: Britain's Annexation of Lagos, 1861.” Journal of Economic History 40, no. 4 (1980): 777-98.

- "The Victorians and Africa: A Reconsideration of the Occupation of Egypt, 1882." Journal of African History 27, no. 2 (1986): 363-91.

Hyam, Ronald. Britain's Imperial Century, 1815-1914: A Study of Empire and Expansion. New York: Barnes \& Noble Books, 1976.

IMF. Export and Import Price Index Manual: Theory and Practice. Washington: International Monetary Fund, 2009.

Inikori, Joseph E. Africans and the Industrial Revolution in England: A Study in International Trade and Economic Development. New York: Cambridge University Press, 2002.

Jacks, David S., Kevin H. O’Rourke, and Jeffrey G. Williamson. “Commodity Price Volatility and World Market Integration since 1720.” Review of Economics and Statistics 93, no. 3 (2011): 800-13.

Jedwab, Remi, and Alexander Moradi. "The Permanent Effects of Transportation Revolutions in Poor Countries: Evidence from Africa." Review of Economics and Statistics 98, no. 2 (2016): 268-84.

Kanya-Forstner, Alexander S. "French African Priorities and the Berlin West Africa Conference.” In Bismarck, Europe, and Africa. The Berlin Africa Conference 1884-1885 and the Onset of Partition, edited by Stig Förster, Wolfgang J. Mommsen, and Ronald Robinson, 171-88. Oxford: Oxford University Press, 1988.

Klein, Herbert S. The Atlantic Slave Trade. Cambridge: Cambridge University Press, 2010.

Law, Robin. "The Historiography of the Commercial Transition in NineteenthCentury West Africa." In African Historiography: Essays in Honour of Ade Ajayi, edited by Toyin Falola, 91-115. Harlow: Longman, 1993.

- ed. From Slave Trade to "Legitimate" Commerce: The Commercial Transition in Nineteenth-Century West Africa. African Studies Series 86. Cambridge: Cambridge University Press, 1995.

_. "Introduction." In From Slave Trade to "Legitimate" Commerce. The Commercial Transition in Nineteenth-Century West Africa, edited by Robin Law, 1-31. Cambridge: Cambridge University Press, 1995.

Lewis, W. Arthur. The Evolution of the International Economic Order. Princeton: Princeton University Press, 1978.

Liesegang, Gerhard, Helma Pasch, and Adam Jones, eds. Figuring African Trade. Berlin: Dietrich Reimer Verlag, 1986.

Lovejoy, Paul E. Slavery, Commerce and Production in the Sokoto Caliphate of West Africa. Trenton, NJ: Africa World Press, 2005.

- Transformations in Slavery: A History of Slavery in Africa. Cambridge: Cambridge University Press, 2011.

Lovejoy, Paul E., and David Richardson. "British Abolition and Its Impact on Slave Prices along the Atlantic Coast of Africa, 1780-1850." Journal of Economic History 55, no. 1 (1995): 98-119.

Lynn, Martin. "The West African Palm Oil Trade in the Nineteenth Century and the 'Crisis of Adaptation'." In From Slave Trade to "Legitimate" Commerce. The Commercial Transition in Nineteenth-Century West Africa, edited by Robin Law, Chapter 2, 57-77. Cambridge: Cambridge University Press, 1995.

Maddison, Angus. Monitoring the World Economy 1820-1992. Paris: OECD, 1995. 
Manning, Patrick. Slavery, Colonialism, and Economic Growth in Dahomey, 16401960. Cambridge: Cambridge University Press, 1982.

Martin, Susan M. Palm Oil and Protest: An Economic History of the Ngwa Region, South-Eastern Nigeria, 1800-1980. Cambridge, NY: Cambridge University Press, 2006.

Meissner, Chris. “A New World Order: Explaining the Emergence of the Classical Gold Standard.” Journal of International Economics 66, no. 2 (2005): 385406.

Meredith, David. "State Controlled Marketing and Economic Development: The Case of West African Produce during the Second World War." Economic History Review 39, no. 1 (1986): 77-91.

Mitchell, Brian R. British Historical Statistics. Cambridge: Cambridge University Press, 1988.

- International Historical Statistics: Europe 1750-2005. Basingstroke: Palgrave Macmillan, 2007.

Mitchener, Kris J., and Marc Weidenmier. Trade and Empire. NBER Working Paper No. 13765, Cambridge, MA, January 2008.

Newbury, Colin Walter. "On the Margins of Empire: The Trade of Western Africa, 1875-1890.” In Bismarck, Europe, and Africa. The Berlin Africa Conference 1884-1885 and the Onset of Partition, edited by Stig Förster, Wolfgang J. Mommsen, and Ronald Robinson, 35-58. Oxford: Oxford University Press, 1988.

Newbury, Colin Walter, and Alexander S. Kanya-Forstner. "French Policy and the Origins of the Scramble for West Africa.” Journal of African History 10, no. 2 (1969): 253-76.

North, Douglas C. “Ocean Freight Rates and Economic Development 1750-1913.” Journal of Economic History 18, no. 4 (1958): 538-55.

Northrup, David. "The Compatibility of the Slave and Palm Oil Trades in the Bight of Biafra.” Journal of African History 17, no. 3 (1976): 353-64.

Obstfeld, Maurice, and Kenneth Rogoff. Foundations of International Macroeconomics. Cambridge, MA: MIT Press, 1996.

Officer, Lawrence H. "Measuring Worth: Dollar-Pound Exchange Rate from 1791.” 2015. http://www.measuringworth.com/exchangepound/.

Pakenham, Thomas. The Scramble for Africa: The White Man's Conquest of the Dark Continent from 1876-1912. New York: Avon Books, 1992.

Pamuk, Sevket, and Jeffrey G. Williamson. "Ottoman De-Industrialization 18001913: Assessing the Shock, Its Impact and the Response.” Economic History Review 64 (February 2011): 159-84.

Panza, Laura, and Jeffrey G. Williamson. "Did Muhammad Ali Foster Industrialization in Early Nineteenth Century Egypt?” Economic History Review 68, no. 1 (2015): 79-100.

Platt, Desmond Christopher M. "Further Objections to an 'Imperialism of Free Trade’, 183060.” Economic History Review 26, no. 1 (1973): 77-91.

Prados de la Escosura, Leandro. "Output per Head in Pre-Independence Africa: Quantitative Conjectures.” Economic History of Developing Regions 27, no. 2 (2012): 1-36.

Prebisch, Raul. The Economic Development of Latin America and Its Principal Problems. Lake Success, NY: UN Department of Economic Affairs, 1950.

Ratcliffe, Barrie M. "The Economics of the Partition of Africa: Methods and Recent Research Trends.” Canadian Journal of African Studies 15, no. 1 (1981): 331.

Richardson, David. "Prices of Slaves in West and West-Central Africa: Toward an Annual Series, 1698-1807.” Bulletin of Economic Research 43 (1991): 21-56.

Robinson, Ronald, and John Gallagher. Africa and the Victorians: the Official Mind of Imperialism. London: MacMillan, 1961. 
Rodney, Walter. How Europe Underdeveloped Africa. London: Bogle-L’Ouverture Publications, 1972.

Roy, Tirthanker. "Economic History and Modern India: Redefining the Link." Journal of Economic Perspectives 16, no. 3 (2002): 109-30.

Sauerbeck, Augustus. "Prices of Commodities and the Precious Metals." Journal of the Statistical Society of London 49, no. 3 (1886): 581-648.

- "Prices of Commodities in 1893." Journal of the Statistical Society of London 57, no. 1 (1894): 172-83.

- "Prices of Commodities in 1904." Journal of the Statistical Society of London 68, no. 1 (1905): 138-53.

. "Prices of Commodities in 1916." Journal of the Statistical Society of London 80, no. 2 (1917): 289-309.

- "Prices of Commodities in 1931." Journal of the Statistical Society of London 95, no. 2 (1932): 303-19.

" "Wholesale Prices in 1950." Journal of the Statistical Society of London 114, no. 3 (1951): 408-22.

Sessions, Jennifer E. By Sword and Plow: France and the Conquest of Algeria. Ithaca, NY: Cornell University Press, 2011.

Sheriff, Abdul. "Ivory and Commercial Expansion in East Africa." In Figuring African Trade, edited by Gerhard Liesegang, Helma Pasch, and Adam Jones, 415-50. Berlin: Dietrich Reimer Verlag, 1986.

- Slaves, Spices and Ivory in Zanzibar: Integration of an East African Commercial Empire into the World Economy, 1770-1873. London: James Currey, 1987.

- "Localisation and Social Composition of the East African Slave Trade, 1858-1873.” Slavery and Abolition 9, no. 3 (1988): 131-45.

Singer, Hans W. "The Distribution of Gains between Investing and Borrowing Countries.” American Economic Review 40, no. 2 (1950): 473-85.

Temperley, Howard. White Dreams, Black Africa: The Antislavery Expedition to the River Niger 1841-1842. New Haven: Yale University Press, 1991.

Thornton, John. Africa and Africans in the Making of the Atlantic World, 14001800. Cambridge: Cambridge University Press, 1998.

Tosh, John. "The Cash Crop Revolution in Tropical Africa: An Agricultural Reappraisal.” African Affairs 79, no. 317 (1980): 79-94.

Waijenburg, Marlous van. Financing the African Colonial State: The Revenue Imperative and Forced Labour. AEHN Working Paper No. 20. Sussex: African Economic History Network, 2015.

Williamson, Jeffrey G. Trade and Poverty: When the Third World Fell Behind. Cambridge, MA: MIT Press, 2011.

\section{PRIMARY SOURCES}

Administration des Douanes. Tableau General du Commerce de la France avec ses Colonies et les Puissance Etrangeres. Paris: Imprimerie Nationale, 1830-1895.

- Tableau General du Commerce et de la Navigation. Volume I. Paris: Imprimerie Nationale, 1896-1928.

_. Tableau General du Commerce Exterieur. Paris: Imprimerie Nationale, 1929-1939.

Board of Trade. Annual Statement of the Trade and Navigation of the United Kingdom with Foreign Countries and British Possessions. London: Eyre and Spottiswoode (1856, 1861, 1866, 1871, 1876, 1881, 1887, 1892, 1897, 1902).

- Statistical Abstract for the United Kingdom in Each of the Last Fifteen Years. London: Eyre and Spottiswoode (1868, 1874, 1887, 1898, 1903, 1907). 
Statistical Abstract for the Several Colonial and Other Possessions of the United Kingdom. London: Eyre and Spottiswoode, 1 (1865); 10 (1874); 20 (1885); 28 (1891); 32 (1895).

- Statistical Abstract for the Several British Colonies, Possessions, and Protectorates. London: His Majesty’s Stationery Office, 43 (1906).

- Statistical Abstract for the Several British Self-Governing Dominions, Crown Colonies, Possessions, and Protectorates. London: His Majesty's Stationery Office, 48 (1911).

- Statistical Abstract for the Several British Oversea Dominions and Protectorates. London: His Majesty’s Stationery Office, 57 (1926).

- Statistical Abstract for the British Empire. London: His Majesty's Stationery Office, 63 (1935); 68 (1939).

- Statistical Abstract for the British Commonwealth. London: His Majesty's Stationery Office, 69 (1947); 70 (1950).

British Customs Ledgers, Ledgers of Imports under Countries, CUST 4. Kew: The National Archives, 1809-1850.

- States of Navigation, Commerce and Revenue, CUST 17. Kew: The National Archives, 1784-1808.

British Foreign and Commonwealth Office. Blue Book for the Gambia. London: Government Printer, 182-1849; 1851-1939.

. Blue Book for the Gold Coast. London: Government Printer, 1846-1861; 1867-1939.

. Blue Book for the Colony of Lagos. London: Government Printer, 18621905.

Blue Book for Nigeria. London: Government Printer, 1914-1939.

Blue Book for Northern Nigeria. London: Government Printer, 1900-1913.

Blue Book for Sierra Leone. London: Government Printer, 1819-1939.

Blue Book for Southern Nigeria. London: Government Printer, 1899-1913.

Cape of Good Hope Blue Book. London: Government Printer, 1821-1904.

. Tanganyika Territory Blue Book. Dar Es Salaam: Government Printer, 1921; 1926; 1931; 1936.

Ministere de l'Agriculture et du Commerce. Annuaire Statistique de la France. Paris: Imprimerie Nationale, 1878-1899.

Ministere du Commerce, de l'Industrie, des Postes et des Telegraphes. Annuaire Statistique. Paris: Imprimerie Nationale, 1900-1939.

U.S. Department of Commerce, Bureau of the Census, Historical Statistics of the United States, Colonial Times to 1970. Washington, DC: GPO, 1975. 


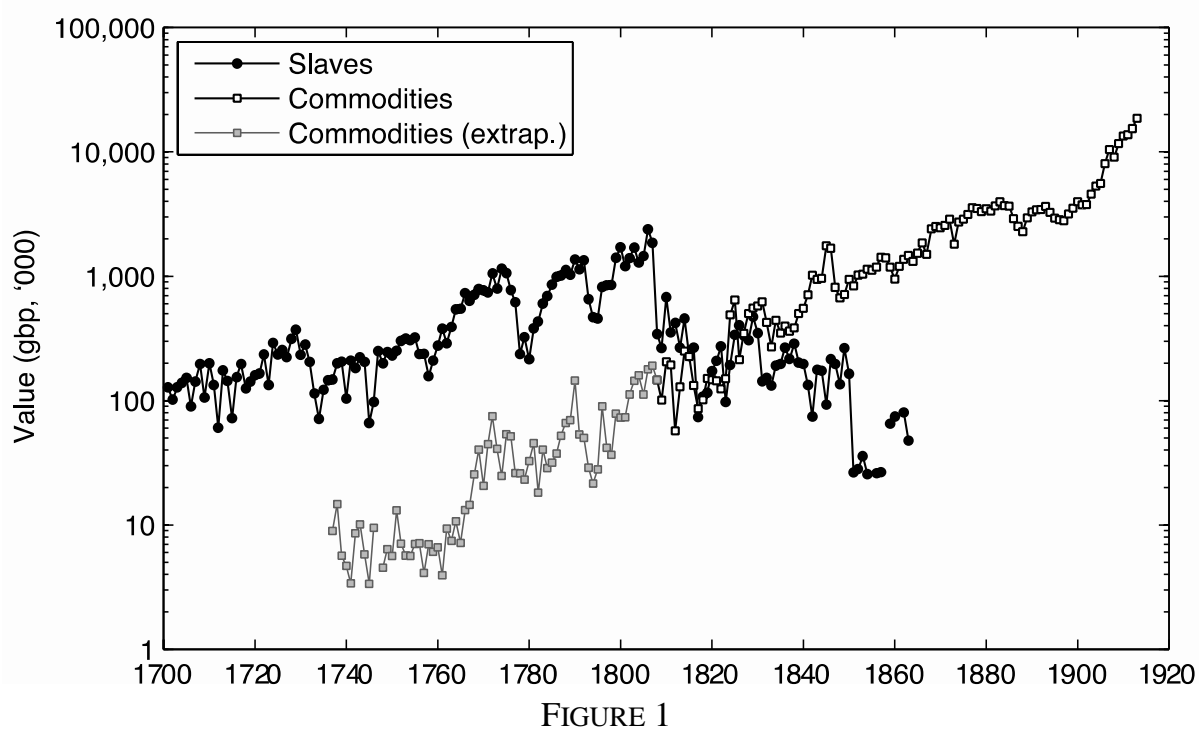

VALUE OF SLAVES AND COMMODITIES FROM WEST AFRICA, 1700-1913

Notes: Value of slaves and commodities in nominal values converted to British Pounds.

Sources: 1808-1913 commodities see notes to Figure 3 and text. 1737-1807 commodity values based on the share of commodities in the total value of trade from West Africa (Dalrymple-Smith and Woltjer 2016). Value of slave trade for West Africa based on slave embarkations from the Transatlantic Slave Trade Database (Eltis and Richardson 2008) and slave prices from Richardson (1991) and Lovejoy and Richardson (1995). 


\section{1: Palm Oil}

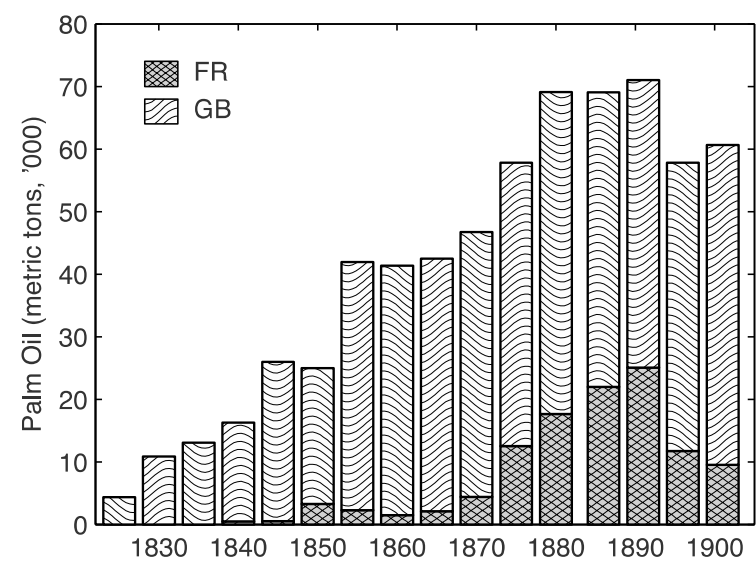

2.3: Nuts and Kernels

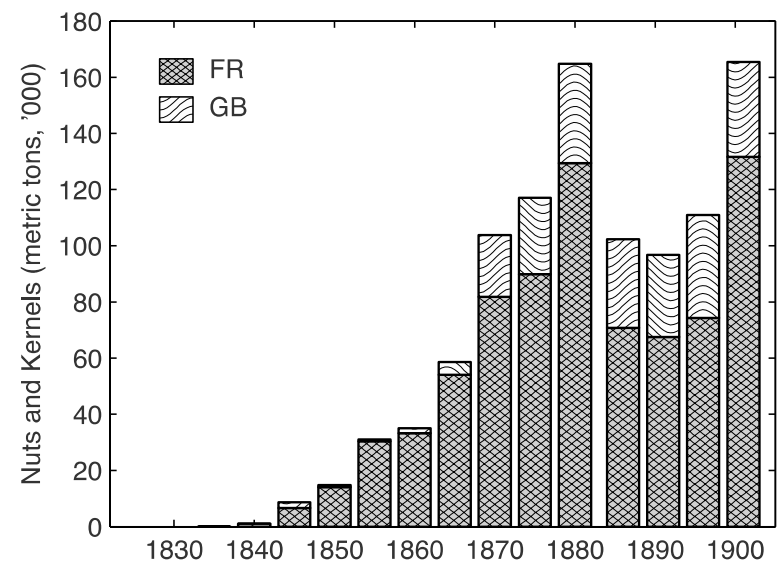

2.2: Gum and Resins

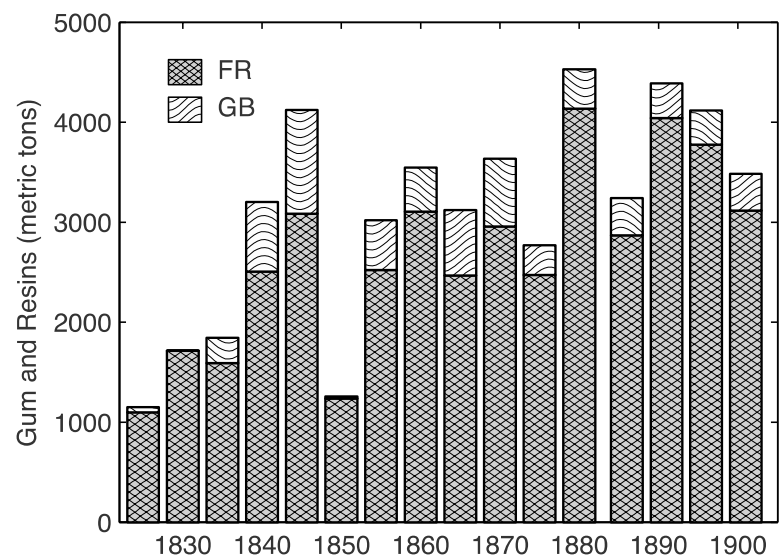

2.4: Ivory

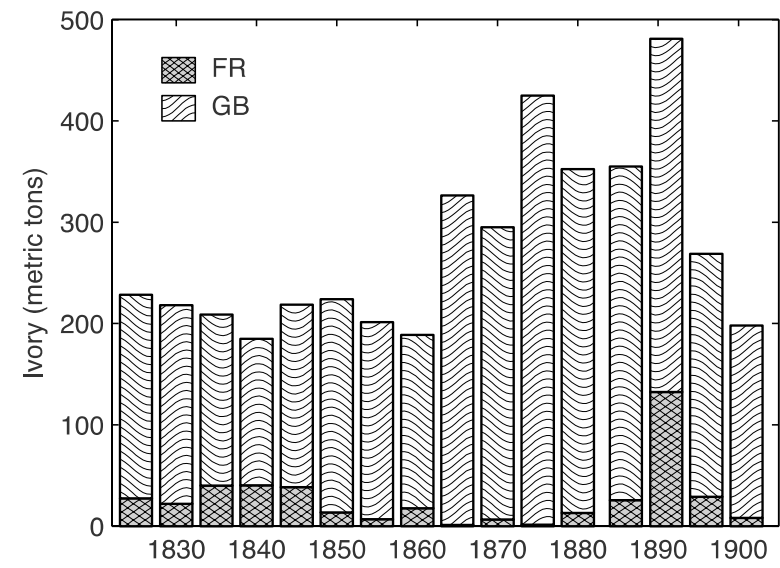

FIGURE 2

KEY COMMODITY EXPORTS FROM WEST AND EAST AFRICA, 1825-1900

Notes: Exports of key African commodities into France and Great Britain respectively. Nuts and Kernels includes Palm Kernels. British possessions' exports of ivory include ivory re-exported via India. The vertical axis for Palm Oil and Nuts and Kernels shows the quantity in thousands of metric tons, whereas the quantity of Ivory and Gum and Resins is given in metric tons. Sources: France, Tableau General du Commerce (1827-1901); Great Britain, British Customs Records (1825-1850), Annual Statement of the Trade and Navigation (1855-1901), Sheriff (1986). 


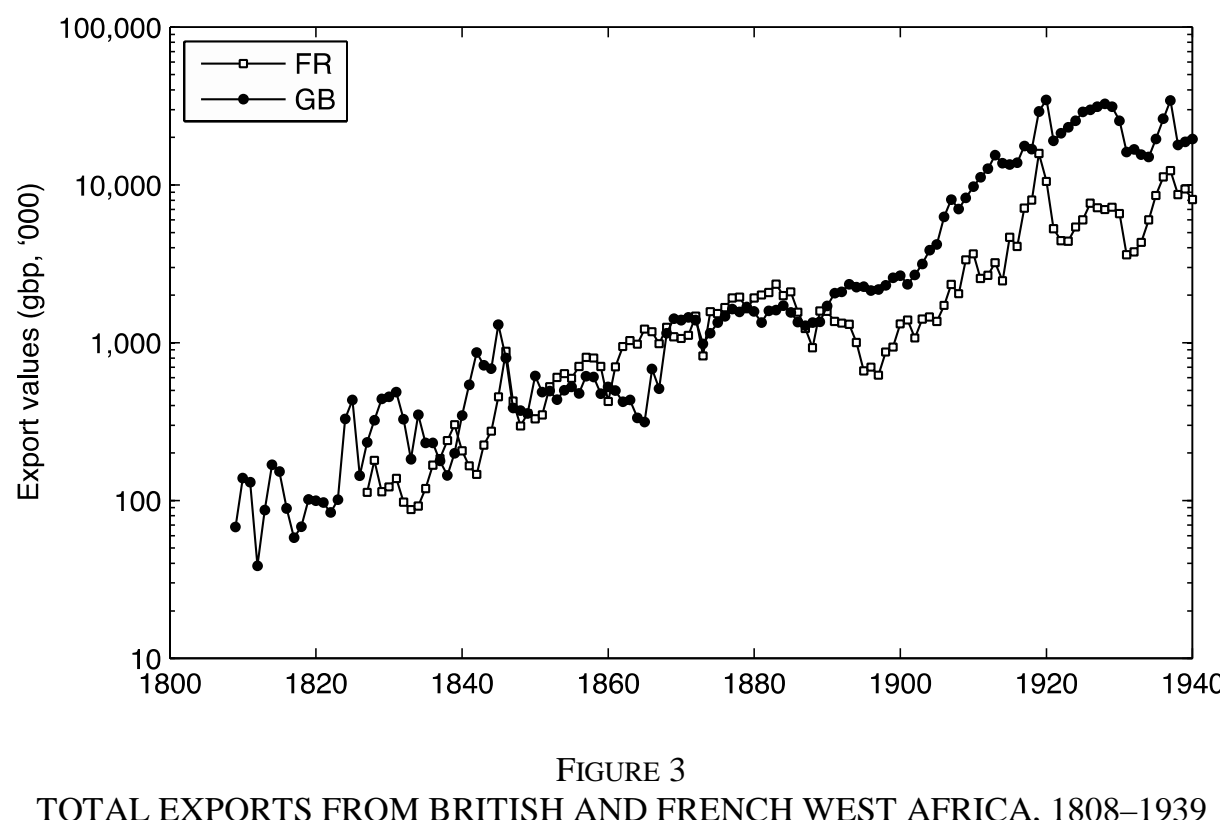

Notes: Total exports in nominal values converted to British Pounds. Pre-1850 data extrapolated based on the aggregate nominal export value of ivory, nuts and kernels, gum and resins, palm oil, wax, pepper and hides. Sources: See text. 


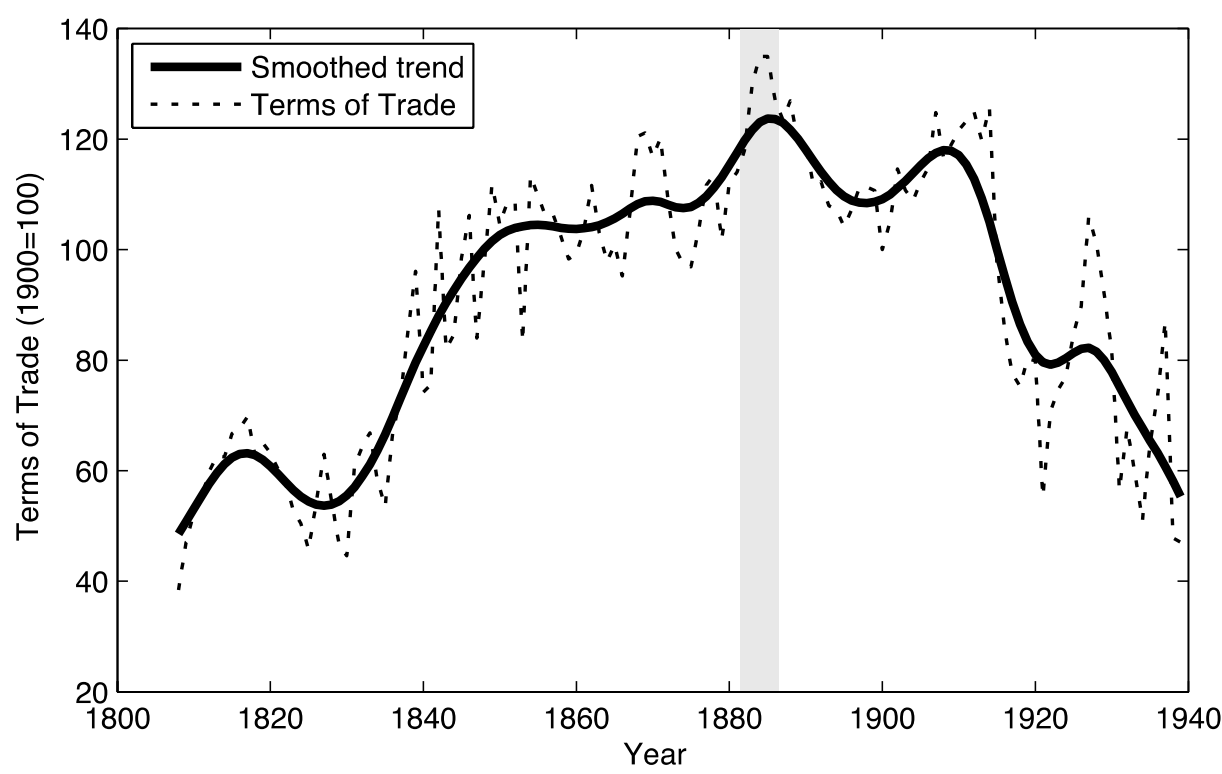

Figure 4

NET BARTER TERMS OF TRADE WEST AFRICA, 1808-1939 (1900=100)

Notes: Smoothed trend derived using Hodrick-Prescott filter, with a smoothing factor set to 100. Sources: See text. 


\section{1: East Africa}

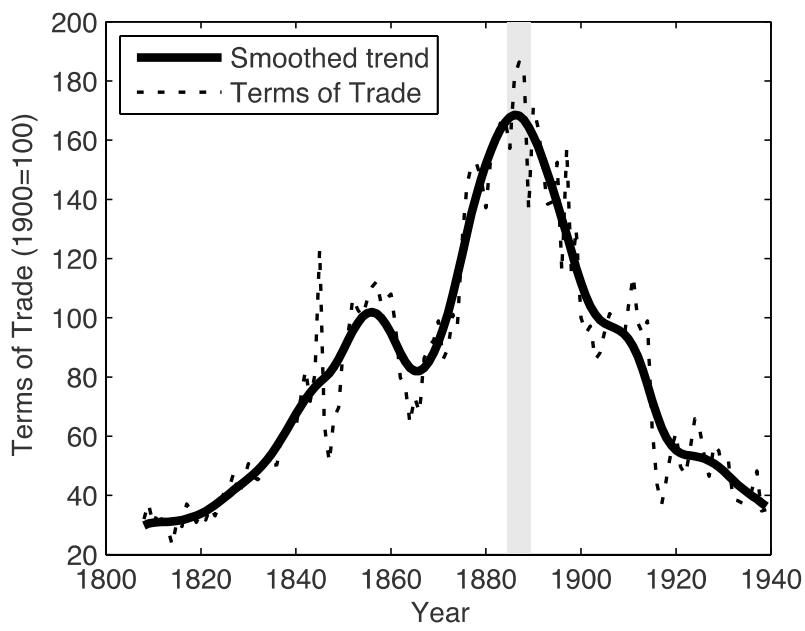

5.3: South-Africa and Southern Rhodesia

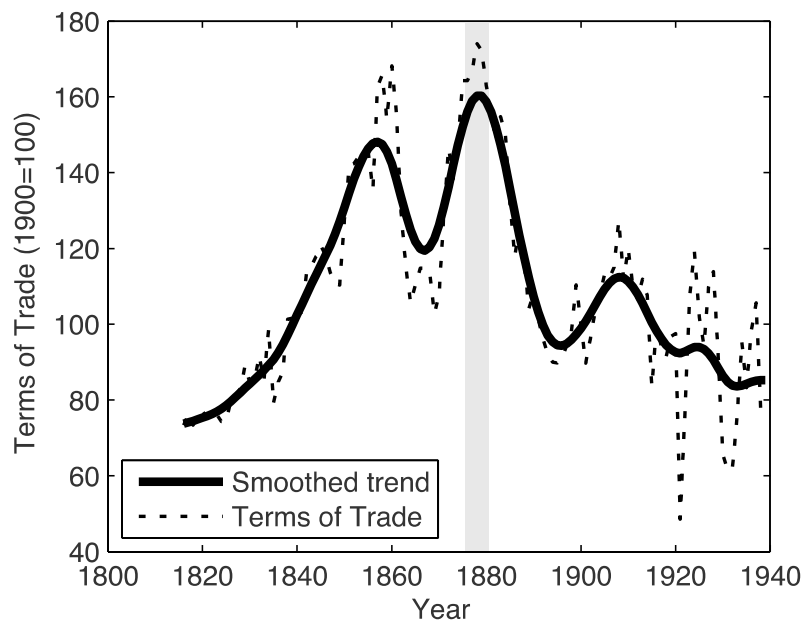

5.2: Mauritius, Madagascar and Reunion

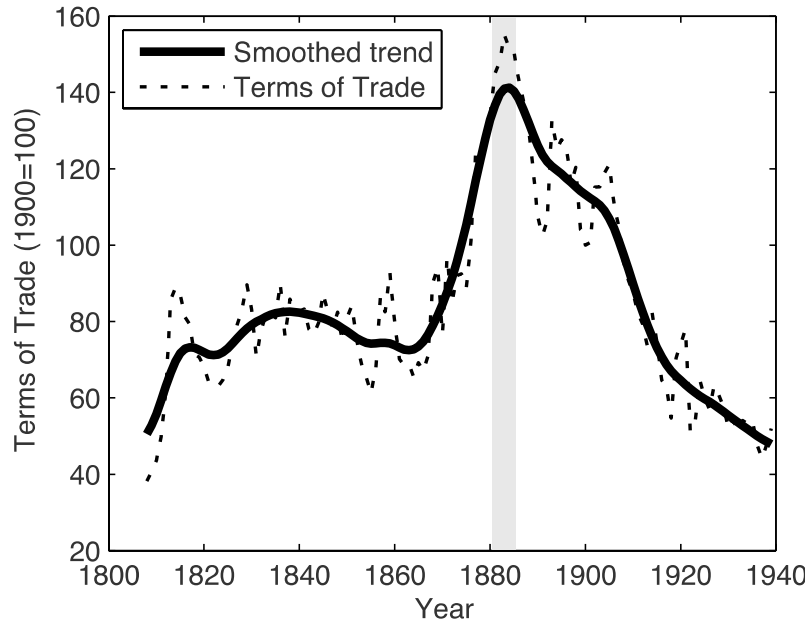

5.4: Egypt

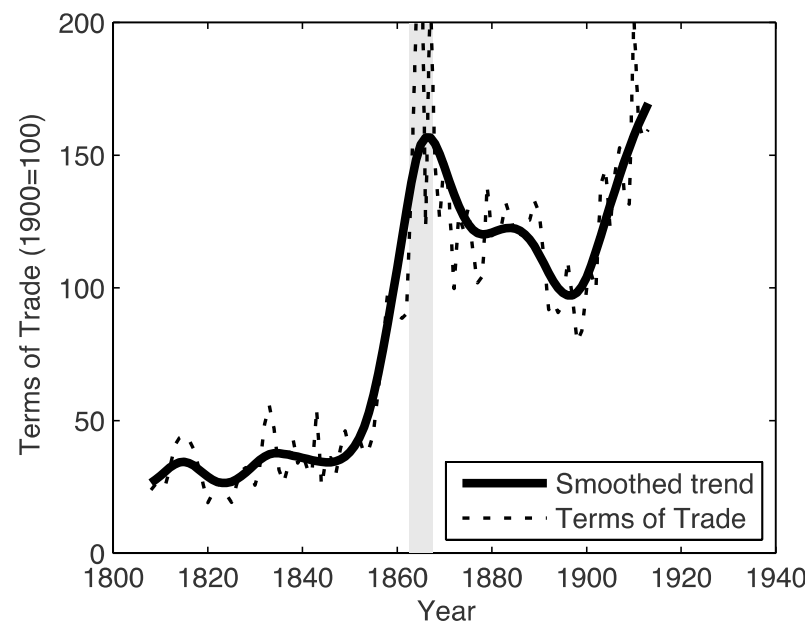

FIGURE 5

Notes: Smoothed trend derived using Hodrick-Prescott filter, with a smoothing factor set to 100 . The scale on the vertical axis differs between the sub-plots.

Sources: See text. 

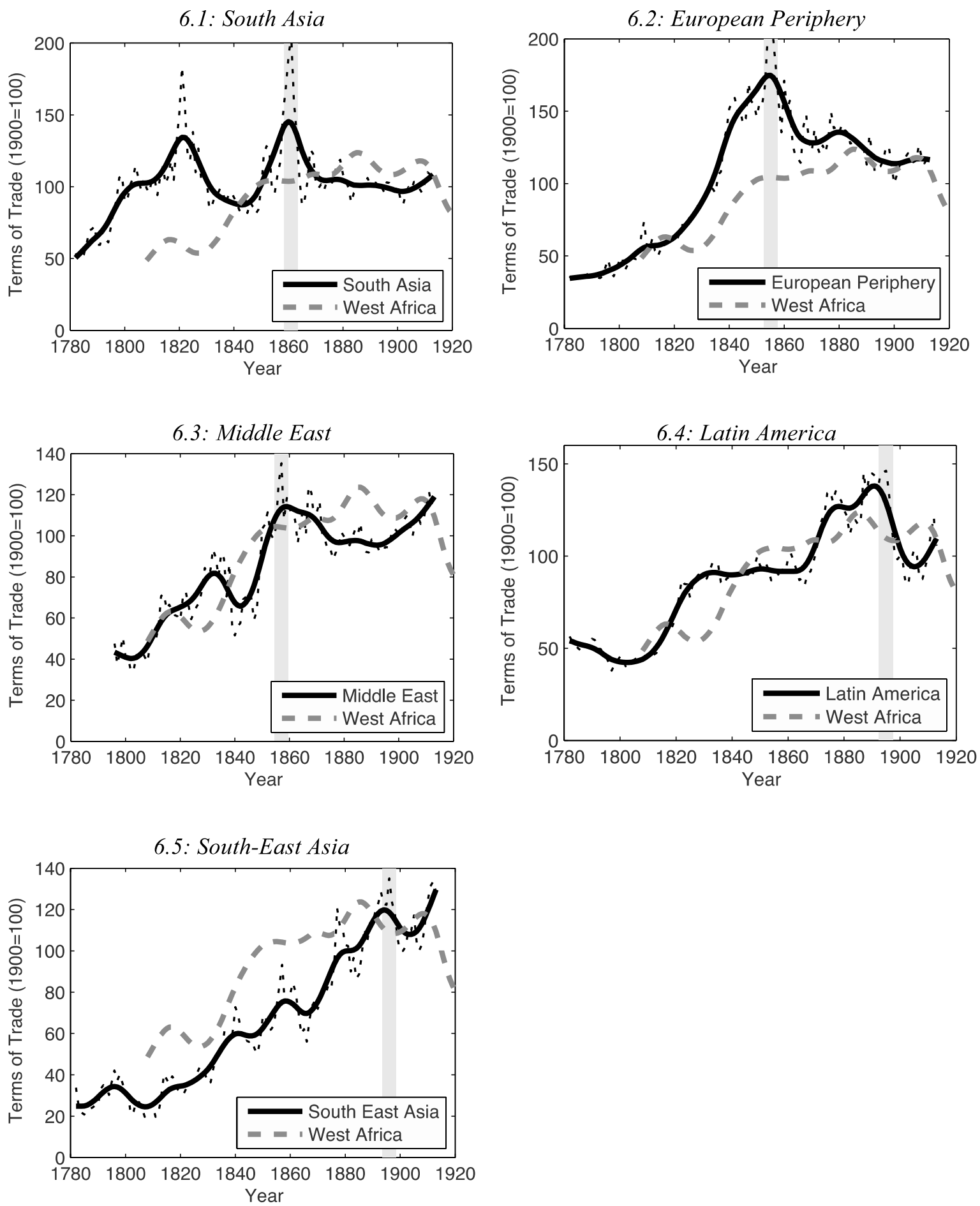

FIGURE 6

TERMS OF TRADE WEST AFRICA AND THE REST OF THE POOR COMMODITY-EXPORTING PERIPHERY, 1784-1913

Notes: Smoothed trend derived using Hodrick-Prescott filter, with a smoothing factor set to 100 . The scale on the vertical axis differs between the sub-plots.

Sources: “Other periphery” from Williamson (2011). "West Africa” see text. 

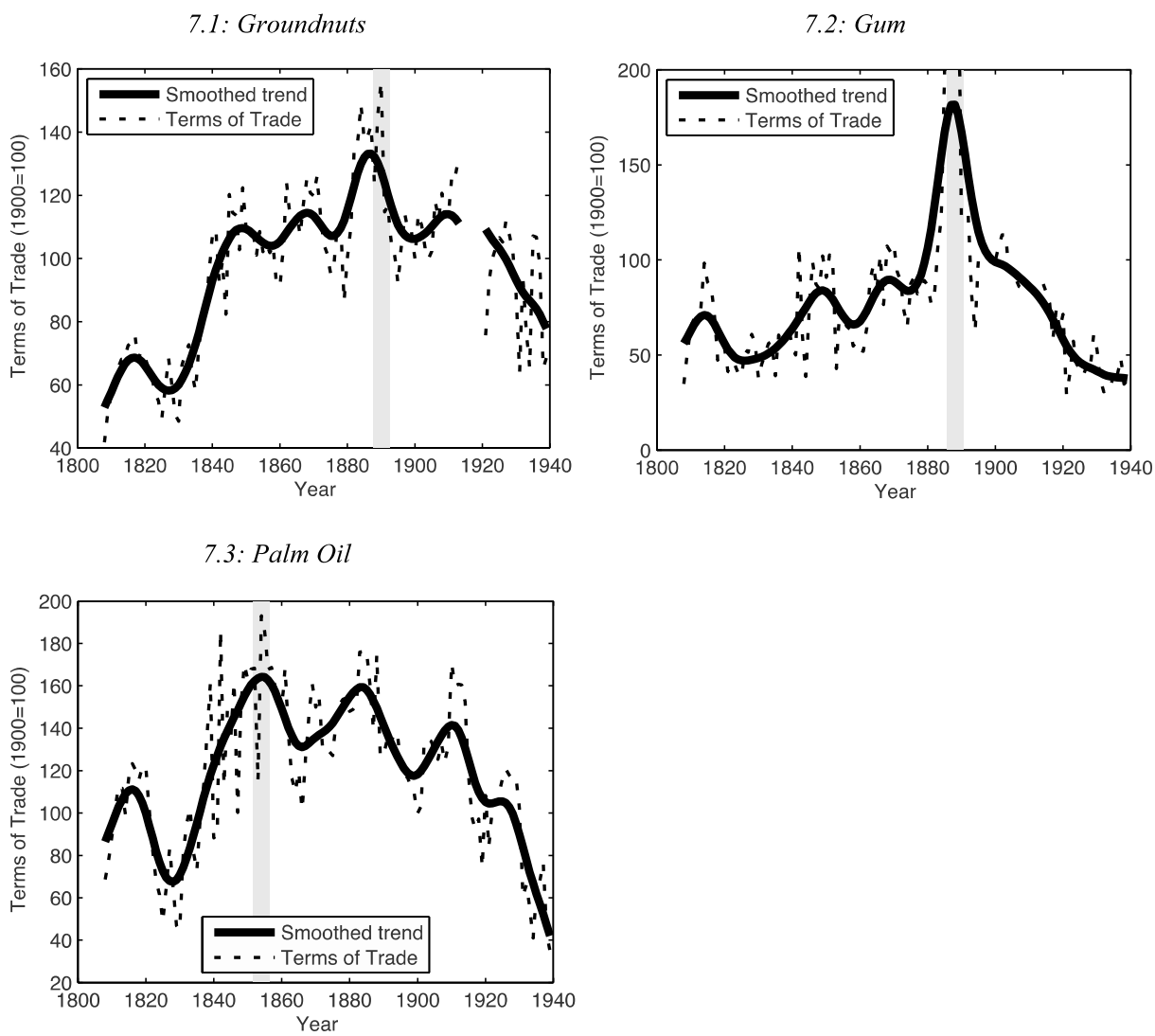

FIGURE 7

COMMODITY SPECIFIC NET BARTER TERMS OF TRADE, WEST AFRICA 1808-1939 (1900=100)

Notes: Smoothed trend derived using Hodrick-Prescott filter, with a smoothing factor set to 100 . The scale on the vertical axis differs between the sub-plots.

Sources: See text. 


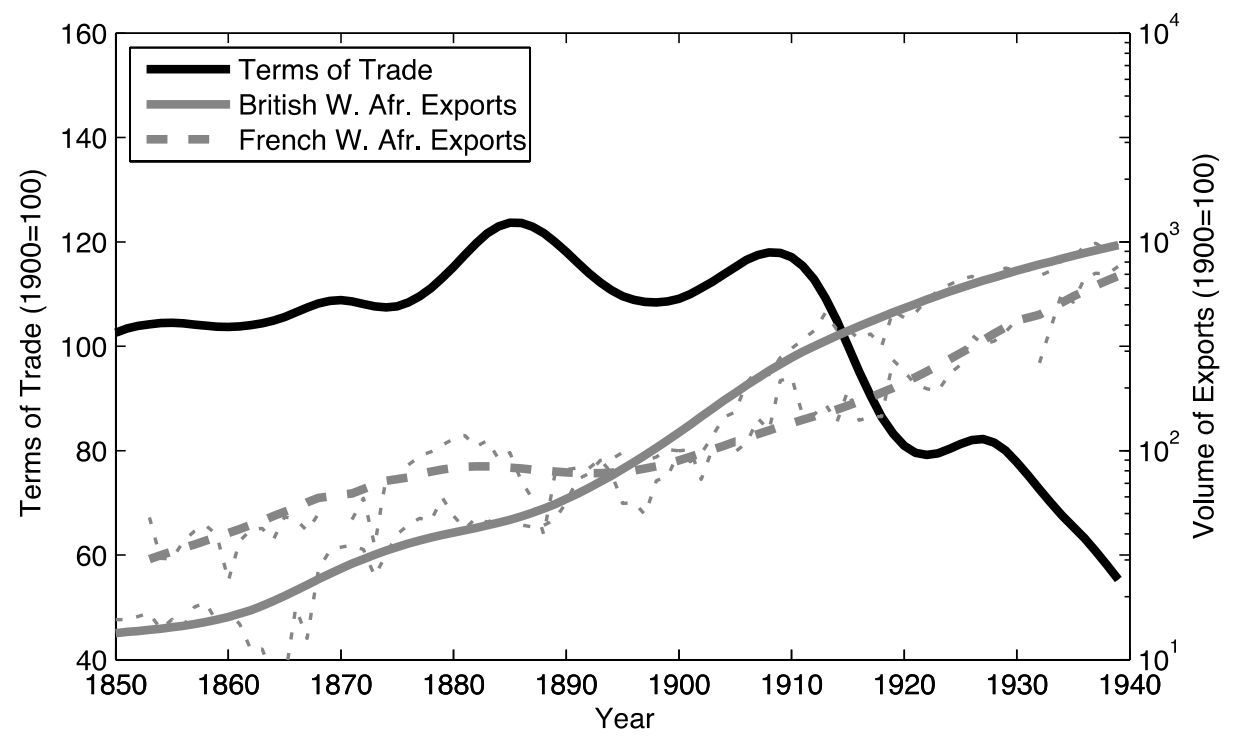

FIGURE 8

TERMS OF TRADE AND VOLUME OF EXPORTS FROM WEST AFRICA, 1850-1939 (1900=100)

Notes: Smoothed trend derived using Hodrick-Prescott filter, with a smoothing factor set to 100 . British and French volumes are the quotient of the nominal export values and a price index of West-African exports.

Sources: “Terms of Trade” see Figure 4; “Nominal Export values” see Figure 3; "Export Price Index” see text. 
TABLE 1A

SHARE OF EXPORTS OF BRITISH COLONIAL POSSESSIONS, 1860-1939 (Percent)

\begin{tabular}{lcccccccc}
\hline \hline Region & $1860 \mathrm{~s}$ & $1870 \mathrm{~s}$ & $1880 \mathrm{~s}$ & $1890 \mathrm{~s}$ & $1900 \mathrm{~s}$ & $1910 \mathrm{~s}$ & $1920 \mathrm{~s}$ & $1930 \mathrm{~s}$ \\
\hline India and Ceylon & 72 & 69 & 70 & 60 & 60 & 55 & 59 & 53 \\
South-East Asia & 11 & 12 & 12 & 15 & 15 & 16 & 20 & 22 \\
Caribbean & 10 & 9 & 7 & 6 & 4 & 4 & 3 & 4 \\
Sub-Saharan Africa & 7 & 10 & 11 & 18 & 21 & 25 & 18 & 21 \\
$\quad$ West Africa & 0.8 & 1.5 & 1.1 & 2.0 & 2.7 & 4.2 & 5.0 & 6.4 \\
$\quad$ East Africa & 0.0 & 0.0 & 0.0 & 0.2 & 0.4 & 1.2 & 1.6 & 4.2 \\
$\quad$ Mauritius & 3.2 & 3.4 & 2.7 & 1.9 & 1.2 & 1.2 & 1.0 & 0.7 \\
$\quad$ South Africa & 3.3 & 4.8 & 6.9 & 13.9 & 16.3 & 18.8 & 10.3 & 10.1 \\
\hline
\end{tabular}

Note: May not sum to total due to rounding.

Source: Statistical Abstracts (various issues).

TABLE 1B

SHARE OF EXPORTS OF FRENCH COLONIAL POSSESSIONS, 1860-1939 (Percent)

\begin{tabular}{lcccccccc}
\hline \hline Region & $1860 \mathrm{~s}$ & $1870 \mathrm{~s}$ & $1880 \mathrm{~s}$ & $1890 \mathrm{~s}$ & $1900 \mathrm{~s}$ & $1910 \mathrm{~s}$ & $1920 \mathrm{~s}$ & $1930 \mathrm{~s}$ \\
\hline French India & 3 & 2 & 5 & 2 & 3 & 2 & 0 & 0 \\
Indochina & 0 & 1 & 1 & 5 & 10 & 12 & 11 & 10 \\
Caribbean & 21 & 17 & 15 & 9 & 6 & 8 & 8 & 6 \\
Other possessions & 11 & 11 & 11 & 10 & 9 & 5 & 5 & 1 \\
Africa & 65 & 70 & 68 & 74 & 72 & 73 & 76 & 82 \\
$\quad$ West Africa & 13.0 & 9.4 & 15.4 & 7.6 & 10.3 & 11.7 & 15.1 & 11.6 \\
$\quad$ East Africa & 0.0 & 0.0 & 0.0 & 0.0 & 0.0 & 0.5 & 0.2 & 0.0 \\
$\quad$ Madagascar and Reunion & 18.5 & 10.2 & 6.1 & 4.6 & 4.2 & 6.7 & 8.3 & 7.0 \\
$\quad$ North Africa & 33.2 & 50.0 & 46.4 & 62.1 & 57.4 & 54.5 & 52.9 & 63.7 \\
\hline
\end{tabular}

Notes: “Other possessions" include St-Pierre-et-Miquelon, New Caledonia, and other French possessions in Oceania. "Madagascar and Reunion” also include Mayotte, Nossi-Be, and Ste-Marie-de-Madagascar. "Caribbean” also includes French Guiana. May not sum to total due to rounding.

Sources: Tableau General du Commerce (1860-1867); Annuaire Statistique de la France (1878-1939).

TABLE 2

AFRICAN TERMS OF TRADE COMPARED, 1791-1853 (1850-1853=100)

\begin{tabular}{lcc}
\hline \hline & Eltis and Jennings (GBTT) & This Study (NBTT) \\
\hline $1808-11$ & & 45.4 \\
$1811-15$ & 48.8 & 60.6 \\
$1816-20$ & 64.8 & 64.9 \\
$1821-25$ & 49.9 & 52.8 \\
$1826-30$ & 49.4 & 51.9 \\
$1831-35$ & 59.1 & 57.4 \\
$1836-40$ & 64.5 & 78.2 \\
$1841-45$ & 67.9 & 88.5 \\
$1846-49$ & 100.0 & 98.8 \\
$1850-53$ & & 100.0 \\
\hline
\end{tabular}

Note: Gross and Net Barter Terms of Trade for West-Africa with England.

Sources: Eltis and Jennings (1988, p. 943); see text. 
TABLE 3

DECOMPOSITION OF EXPORT GROWTH IN BRITISH AND FRENCH WEST AFRICA, 1853-1929

\begin{tabular}{|c|c|c|c|c|c|c|}
\hline \multicolumn{5}{|c|}{ Annual Average Growth (Percent) } & \multicolumn{2}{|c|}{ Contribution (Percent) } \\
\hline & $\begin{array}{c}\text { Purchasing Power } \\
\text { of Export } \\
(1) \\
\end{array}$ & $\begin{array}{l}\text { Import } \\
\text { Price } \\
(2)\end{array}$ & $\begin{array}{l}\text { Export Price } \\
\text { (3) }\end{array}$ & $\begin{array}{c}\text { Export } \\
\text { Volume } \\
\text { (4) }\end{array}$ & $\begin{array}{l}\text { Price } \\
\text { (5) }\end{array}$ & $\begin{array}{c}\text { Volume } \\
\text { (6) }\end{array}$ \\
\hline \multicolumn{7}{|c|}{ British West Africa $(£)$} \\
\hline 1853-1885 & 4.65 & -0.68 & 0.83 & 3.14 & 32 & 68 \\
\hline 1885-1929 & 5.49 & 1.32 & 0.46 & 6.36 & -16 & 116 \\
\hline \multicolumn{7}{|c|}{ French West Africa (Fr.) } \\
\hline $1853-1885$ & 4.96 & -1.06 & 1.67 & 2.23 & 55 & 45 \\
\hline 1885-1929 & 1.98 & 4.43 & 3.38 & 3.03 & -53 & 153 \\
\hline
\end{tabular}

Notes: Growth rate in natural logs. The purchasing power of export in column (1) is the sum of columns (3) and (4) minus (2). The price contribution is the difference between columns (3) and (2) divided by (1). The volume contribution is the ratio of (4) and (1). May not sum to total due to rounding.

Sources: British "Import Price” from Mitchell (1988); French "Import Price” from Mitchell (2007); British "Export Values” from Statistical Abstracts (various issues); French "Export Values” from Tableau General du Commerce (1860-1867); Annuaire Statistique de la France (1878-1939); British and French export price see text.

TABLE 4

TERMS OF TRADE IN THE PERIPHERY, AFRICAN GROWTH RATES IN PERSPECTIVE (PERCENT)

\begin{tabular}{lccc}
\hline \multicolumn{1}{c}{ Region } & & & $\begin{array}{c}\text { Annual Growth } \\
\text { Start to Peak } \\
\text { (Percent) }\end{array}$ \\
\hline All periphery (ex. East Asia and Africa) & Starting Year & Peak Year & 1.43 \\
European periphery & 1796 & 1860 & 2.43 \\
Latin America & 1782 & 1855 & 0.87 \\
Middle East & 1782 & 1895 & 1.68 \\
South Asia & 1796 & 1857 & 0.90 \\
South-East Asia & 1782 & 1861 & 1.42 \\
Sub-Saharan Africa (ex. South Africa) & 1782 & 1896 & 1.73 \\
West Africa & 1808 & 1885 & 1.65 \\
East Africa & 1808 & 1884 & 2.23 \\
Mauritius, Madagascar and Reunion & 1808 & 1887 & 1.87 \\
South Africa & 1808 & 1883 & 1.39 \\
Egypt & 1816 & 1878 & 4.30 \\
\hline
\end{tabular}

Note: Growth rate in natural logs.

Sources: “Other periphery” from Williamson (2011). “Africa” see text. 